University of Louisville

ThinkIR: The University of Louisville's Institutional Repository

Electronic Theses and Dissertations

$5-2012$

\title{
To the mountaintop and back again : the rise and fall of General George B. McClellan.
}

Carl Pagles 1977-

University of Louisville

Follow this and additional works at: https://ir.library.louisville.edu/etd

\section{Recommended Citation}

Pagles, Carl 1977-, "To the mountaintop and back again : the rise and fall of General George B. McClellan." (2012). Electronic Theses and Dissertations. Paper 1089.

https://doi.org/10.18297/etd/1089

This Master's Thesis is brought to you for free and open access by ThinkIR: The University of Louisville's Institutional Repository. It has been accepted for inclusion in Electronic Theses and Dissertations by an authorized administrator of ThinkIR: The University of Louisville's Institutional Repository. This title appears here courtesy of the author, who has retained all other copyrights. For more information, please contact thinkir@louisville.edu. 
TO THE MOUNTAINTOP AND BACK AGAIN:

THE RISE AND FALL OF GENERAL GEORGE B. MCCLELLAN

By

Carl Wesley Pagles

B.S. Cumberland College, 1999

\begin{abstract}
A Thesis
Submitted to the Faculty of the

College of Arts and Sciences

Of the University of Louisville

In Partial Fulfillment of the Requirements

for the Degree of
\end{abstract}

Master of Arts

Department of History

University of Louisville

Louisville, Kentucky

May 2012 
TO THE MOUNTAINTOP AND BACK AGAIN:

THE RISE AND FALL OF GENERAL GEORGE B. MCCLELLAN

By

Carl Wesley Pagles

B.S., Cumberland College, 1999

A Thesis Approved on

April 11, 2012

by the following Thesis Committee:

Thomas C. Mackey

Thesis Director

Gary Gregg

Daniel Krebs 
TABLE OF CONTENTS

PAGE

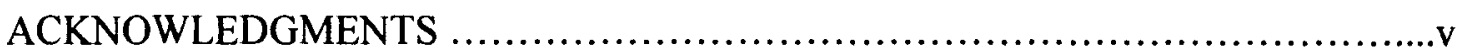

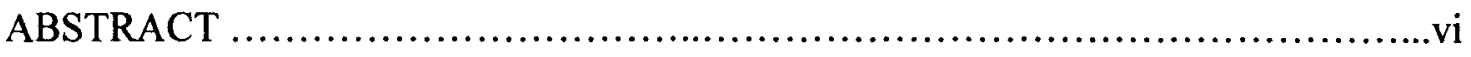

CHAPTER

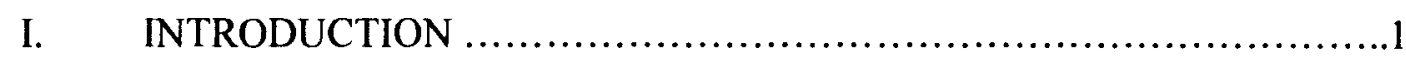

II. SAINT AND SINNER: MCCLELLAN'S HISTORIOGRAPHY ...........8

McClellan Hagiographies: 1880-1910s ...............................9

Post-World War II and the Emergence of T. Harry Williams ..............13

McClellan and the Social Historians ..................................18

Stephen Sears and Modern Historians ....................................20

III. MCCLELLAN AND HIS HISTORICAL MOMENT …....................27

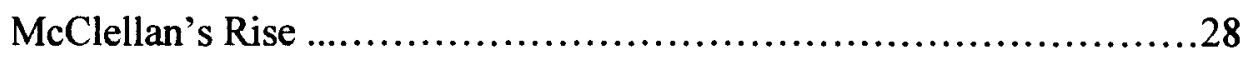

McClellan's Stay at the Top .............................................

McClellan's Fall from Grace .....................................44

IV. MCCLELLAN AND DUAL REALITY ...............................48

Early Distortions of Troop Strength ..................................49

McClellan, Troop Numbers and Peninsula and Maryland Campaigns ...51

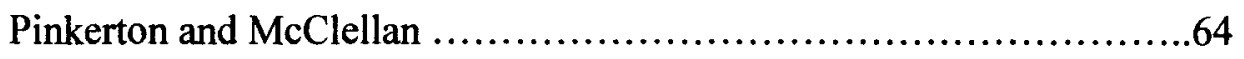

V. THE ARROGANCE OF MCCLELLAN .................................67

George McClellan and the Western Theater ..........................69 
McClellan's Rise to General-in-Chief .

.72

Unabashed Arrogance: The Fall of General George McClellan ...........82

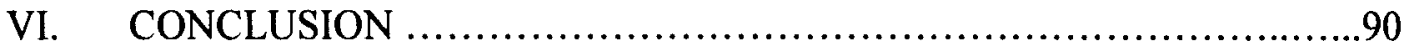

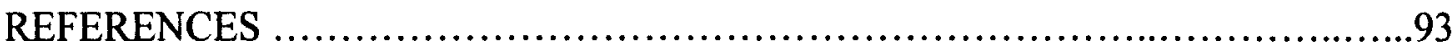

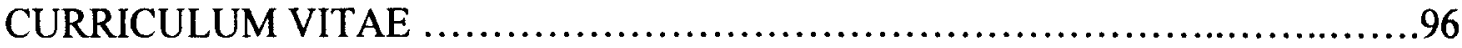




\section{ACKNOWLEDGEMENTS}

I would like to thank my thesis advisor, Dr. Thomas Mackey, for his guidance and insight into the world of General George McClellan. I would also like to thank the other committee members, Dr. Daniel Krebs and Dr. Gary Gregg, for their comments and assistance in the shaping of this thesis. I would also like to express my thanks to my best friend and wife to be, Lena, for her unwavering support. She was a one woman cheerleading squad and had faith in me when I had none. I would also like to thank my family in the Knoxville, Tennessee area, my parents Carl and Kathy Pagles, my sister Heather Pagles, and her partner Holly Sebesta. 


\section{ABSTRACT \\ TO THE MOUNTAINTOP AND BACK AGAIN: \\ THE RISE AND FALL OF GENERAL GEORGE B. MCCLELLAN \\ Carl Wesley Pagles}

April 11, 2012

This thesis is an examination of the factors that impacted the rise and fall of the military career of General George McClellan during the initial stages of the Civil War. It works almost exclusively with primary sources to gain a better understanding of General McClellan through his personal and professional correspondence. The thesis begins with a historiography of the scholars that have examined McClellan from the early days after the Civil War to those of the twenty-first century. The historiography is used as a framework for the debate about the rise and fall of General McClellan. The next three chapters deal exclusively with the factors themselves; starting with McClellan and the historical moment, then McClellan's disconnection with reality in relation to troop movements and numbers, and finishing with McClellan's arrogance/hubris towards both superiors and subordinates. 


\section{CHAPTER I}

\section{INTRODUCTION}

The spring of 1861 proved a tumultuous time for the United States. Throughout the winter of 1860-61, seven southern states seceded from the Union in an effort, according to their claims, to uphold their notions of liberty. Although the nation had dealt with a number of changes throughout the winter, including the secession of southern states and the election of a new president, Abraham Lincoln, the nation was not prepared for the events of April 12,1861. Confederate forces stationed within the city of Charleston fired on Fort Sumter, a Union-held fortress in Charleston harbor. With that act, the Confederacy hastened the beginning of a conflict that lasted four bloody years; a conflict that plunged the nation into a struggle for its very existence.

One man believed that he was called to put an end to the struggle and bring the wayward states back into the Union -- George B. McClellan. Although McClellan served as the vice president of the Illinois Central Railroad when hostilities commenced, he felt that the nation had called him to come to its rescue. McClellan was not an unknown in military circles. He had attended the United States Military Academy at West Point, fought in the Mexican War, led an expedition to find a route for a railroad in the Cascade Mountains, and been part of an expedition to the Crimea to analyze the fortifications and arms of the Russian and French forces during the Crimean War. Fellow officers considered him to be a capable soldier due to his past experience who was on his way to a 
great future when he resigned from the army in 1856. These experiences and traits allowed McClellan to re-enter into the Union forces at the beginning of the Civil War. However, it would be his personal traits that had been overlooked or undiscovered by his superiors that played a pivotal and even tragic role in General McClellan's military career.

Civil War scholar Stephen W. Sears called McClellan "a man possessed by demons and delusions," which led him to make puzzling decisions throughout his tenure in the army during the Civil War. ${ }^{1}$ Although many scholars consider McClellan to have failed during his command, McClellan established some services within the Union Army used throughout the war. Scholars also regard him as the architect of the Army of the Potomac, a fighting force that, in time, eventually ended the Civil War in the Union's favor. His ability to train and equip his troops was equal to any general that either side fielded during the war. McClellan loved his troops and they, in turn, loved him. He created a corps system that the Union used throughout the Civil War. However, McClellan also possessed an abrasive personality that destroyed many of the relationships he developed while in command. His hubristic approach to both those in superior and subordinate positions led to a breakdown in the Union cause, a lack of unity of command, during the early stages of the Civil War. Although McClellan was not the sole cause for the stagnation of the Union war effort at the beginning of the conflict, it was his decision-making processes that led to many of the errors the Union made during that time. His unwillingness to listen to the advice of others, including his military superiors, the Secretary of War, and the President led to infighting within the upper

\footnotetext{
${ }^{1}$ Stephen W. Sears, George B. McClellan: The Young Napoleon (New York: Da Capo Press, 1988), xi.
} 
echelon of the Union's military hierarchy. While the infighting did not lead to a loss by McClellan on the battlefield, it created a sense between all parties that the none of the others could be trusted. McClellan was not comfortable going to his superiors because he felt that they were beneath him. Likewise, his superiors and those in the Lincoln administration, did not go to him with suggestions because of his gruffness, inaccessibility, and at times sheer arrogance.

Many military leaders have had problems with their superiors and subordinates. What made General McClellan compelling was his disregard for all other views that did not fit into his view of the world. Instead of working within the contextual framework given, he complained, cajoled, and strong-armed those around him. Although McClellan proved successful in some instances, for the most part his antics led to a lessening of good will between himself, his military superiors and subordinates, and the Lincoln administration. Instead of taking the advice of those around him, McClellan believed that his decisions were the best for his army and the country. This personality trait was as vexing to the administration as it has been to the scholarly community studying him. This trait also led to many scholars to not attempt to understand McClellan. He was too puzzling to tackle. They could not understand how a man could be in command of such a large force and make the decisions that he did. But, this inconsistency intrigues. There have to be answers to the questions that have vexed so many other scholars.

This essay does not take sides in the argument of whether McClellan was a "good" or "bad" general, instead it is intended to examine the reasons why he rose and fell in the Union ranks so quickly. This essay is not an indictment or exoneration of General George McClellan; instead, it is an analysis of his rise and fall, how he rose to 
the top of the military hierarchy in the fall of 1861 only to fall into obscurity one year later. This effort focuses on three main factors that attributed to his rise and fall: the historical moments that coincided with McClellan's rise and fall, McClellan's dual reality; in essence how differently he saw the world as opposed to those around him, and his arrogance/hubris towards both his superiors and subordinates. The essay analyzes McClellan's professional and personal correspondence in order to glean his motivations behind many of his decisions. Although based on secondary sources to provide a modern analysis of McClellan, the primary sources constituted the best evidence in the examination of his rise and fall.

Because of his enigmatic personality, scholars have been reluctant to focus their studies on McClellan. While scholars have produced volumes about Generals Grant, Sherman, and Lee; a lack of scholarship centered on McClellan exists. It is interesting that the man who created the Army of the Potomac has been relegated to the periphery, a cautionary tale on how not to command an army. Little analysis exists on the reasoning behind why scholars consider McClellan a failure and most of that scholarship has come in the recent past. While many scholars explained why one side or the other is correct in the debate about McClellan, few sources exist that deal with the possible reasons behind his rise and fall without falling into that trap. This essay strays from those sources that took a negative or positive position; instead it focused more on how the factors described above led to the eventual outcome. The essay is divided into four different chapters: historiography, historical moment, dual reality, and personality.

The first chapter of this essay examines the scholarship pertaining to McClellan, starting with the hagiographies of the late nineteenth century, winding its way through the 
mid-twentieth century with a mixture of hagiographic and scholarly works until finishing with the much more analytical approaches at the turn of the twenty-first century. While many of the works take sides on the "good" general "bad" general argument, enough examples exist of relatively unbiased scholarship to understand the rise and fall of General George McClellan.

The second chapter analyzes the historical moment of McClellan's ascension and descent. That chapter examines how the Unites States constructed its Army during the initial stages of the Civil War. It also evaluates the rolls of graduating classes at the Unites States Military Academy at West Point to gain a clearer picture of who was in the army at the start of hostilities. For comparative purposes, the chapter further delves into what was happening in the lives of two generals that would later lead the Union to victory, Ulysses S. Grant and William T. Sherman, during the beginning stages of the conflict. The chapter also examines the political context of his appointment first as commander of the troops from Ohio and later as the commander of all the Union forces. As a moderate Democrat, McClellan had the full backing of the Democrats as well as several conservative Republicans. Along with the support of these political figures he had the full backing of many of the conservative publications throughout the Union. These publications highlighted his strengths without noting his deficiencies. Because of these affiliations and political connections, McClellan was a much more palatable choice for President Lincoln as he attempted to keep the rest of the Union together. Finally, the chapter scrutinizes the reasons why President Abraham Lincoln allowed McClellan to stay in command after his many missteps.

The third chapter examines McClellan's dual reality. Dual reality defined in this 
context is that McClellan lived in one reality while the rest of the world lived in a separate reality. No matter how many times these two realities clashed, McClellan continued to live in his own reality. Thus, McClellan's distinct reality allowed him to make decisions that others living in true reality did not understand. The most pertinent example of this dual reality was that McClellan believed his army was continually fighting a much larger adversary while at the same time having a smaller force in which fight them. McClellan made multiple claims of a Confederate fighting force that was at times four to five times the actual size of the enemy's forces. Throughout his time as commander he called for reinforcements, even when no imminent threat to his forces or to Washington DC existed. His constant call for reinforcements led many in the Lincoln administration to believe that McClellan would not take advantage of any edge that he had on the battlefield. The disagreements between McClellan and his opponents within the administration thus led to his downfall.

The final chapter evaluates General McClellan's personality, most notably his arrogant, bordering on hubristic, attitude towards his superiors and subordinates. McClellan's arrogance permeated throughout his time as a General within the Union army during the Civil War. Although his arrogance had shown itself at various times earlier in his life, his arrogance came to full bloom during his time as a commander in the Civil War. He was unwilling to listen to the advice given to him by his superiors, even when the advice came from President Lincoln. He also had no confidence in many of his subordinate commanders believing that he was the only officer that could lead his troops to victory, even though he took credit for many of the victories by his subordinate commanders, especially during his campaign into the Kanawa Valley in western Virginia. 
The chapter provides numerous examples of his arrogance: his continued writing to President Lincoln without going through the appropriate military channels, his use of unflattering names when describing his superiors and subordinates, and his ambitions of becoming a dictator so that he could lead the country to victory on his own terms. All of these examples led to only once conclusion; McClellan believed that he was a better commander, statesmen, and person. If anyone called into question McClellan's methods or thought processes, he immediately discounted them as being jealous of his military and political genius.

General George McClellan's successes and failures can be attributed to different reasons. Some scholars have examined the weather patterns of his Peninsula Campaign during the summer of 1862 and its increased rainfall as the overarching reason for its failure. Others have analyzed the political side of the argument that the Lincoln administration did not allow McClellan to succeed because he was a moderate Democrat and did not fit into the mold that the administration wanted. Still others point to the overall generalship of the Confederates; they argue that while McClellan proved an able commander, the Confederacy just had better commanders. Although some of these theses have merit, the key to understanding McClellan's rise and fall centers on the three main reasons in this essay: the historical moment, McClellan's dual reality, and McClellan's hubris. 


\section{CHAPTER II}

\section{SAINT AND SINNER: MCCLELLAN'S HISTORIOGRAPHY}

Few generals in the American Civil war are more enigmatic than General George B. McClellan. Born of a prominent family in Philadelphia, McClellan attended West Point beginning in 1842. Following graduation in 1846, McClellan fought in the Mexican War, then became part of a military mission to the Crimea, and later tried his hand at running a railroad company. At the onset of the Civil War, after the outbreak of hostilities in April 1861, McClellan joined the Union cause. Based on a number of factors including his experience, knowledge and political connections, President Abraham Lincoln quickly promoted him to General-in-Chief and Commander of the Army of the Potomac later that same year. While commander, McClellan directed two campaigns that ended in neither defeat nor victory, but in November 1862 , due to his lack of success on the battlefield, President Abraham Lincoln stripped him of his command. While McClellan has not been studied as exhaustively as General Robert E. Lee and General Ulysses S. Grant, he has been the subject, or at least a major player, in a variety of books, articles, and dissertations by scholars from the end of the Civil War until the present time. Although a large volume of scholarship exists, McClellan has been a difficult subject for historians. He can be seen as a noble figure, the claimant to the mantle of savior of the Union and a petty, self-serving egotist who saw the faults in others that he could not see in himself.

This duality creates a problem for any scholar that studies McClellan. In past 
generations, historians and writers have placed McClellan in strict parameters, not allowing for behaviors that undermined their theses. Even in the current body of literature on McClellan, some authors are unable to detach themselves from the thought processes of past writers.

For ease of reference, the historiographical scholarship that follows will be broken into four distinct parts. The first part examines the hagiographical nature of the first essays about McClellan dating from the 1880s to 1916. The second part focuses on scholarship from historians in post-World War II America to the emergence of T. Harry Williams during the $1950 \mathrm{~s}$. The third section reviews the rise of social history in the early 1960s that incorporated new interpretations of McClellan, most which were not laudatory of the former General-in-Chief. Finally, the essay explores how the publication of Stephen Sears' 1988 McClellan: The Young Napoleon opened new avenues for scholarship throughout the 1990 s to the present day. This essay focuses primarily on one or two prime or exemplary examples of each one of the time periods, with the full understanding that there are numerous titles in each time period that could be reviewed.

\section{McClellan Hagiographies: 1880-1910s}

After the Civil War, numerous biographies were written by scholars about the major players associated with the outbreak of hostilities. Authors of the era penned hagiographic essays about Robert E. Lee, Ulysses S. Grant, and William T. Sherman. George B. McClellan was no exception. According to Joseph L. Hirsh in "On the McClellan-Go-Round" from a June 1973 article in Civil War History, authors wrote various types of biographies about McClellan, from romantic interpretation to a lawyer's 
brief. $^{2}$ The only common thread between these works was a glowing review of McClellan's life and deeds during the Civil War. Each of these works mentioned McClellan's Christian virtues, his unwavering patriotism to the cause of the Union, his utmost integrity in every aspect of his life, and his unequalled mastery of strategy and military matters. ${ }^{3}$ Although each one of the biographers who examined McClellan during this time did so with an uncritical and romantic eye, one book stands above the rest in terms of an hagiographical work.

McClellan's Own Story, compiled in 1887 after McClellan's death by his close friend William C. Prime, is a retelling of reports and personal letters written during the war. ${ }^{4}$ Three interesting aspects of this work stand out. First, it was completed after the death of McClellan even though scholars have wrongly considered it an autobiography. Second, Prime inserted sections, detailing troop numbers and enemy positions, that McClellan had refuted in the 1870s. Finally, Prime wrote a biographical sketch about the general at the beginning of the book that is the most interesting, and entertaining, example of hagiography written about McClellan during the era. Although the sketch is

${ }^{2}$ Joseph L. Hirsh, "On the McClellan-Go-Round," Civil War History, 19 (June 1973): 102.

${ }^{3}$ Ibid., 103.

${ }^{4}$ George B. McClellan, McClellan's Own Story, ed. by William C. Prime (New York: Charles L. Webster, 1887). Although this biography is the most famous of the hagiographies, many other offer interesting views of revisionist history. For further reading see Markinfield Addey, George Brinton McClellan: from Cadet to MajorGeneral: A Biography. (New York: James G. Gregory, 1864); George Ticknor Curtis, "McClellan's Last Service to the Republic, Part I," The North American Review, 130 (April 1880 ); George Ticknor Curtis, "McClellan's Last Service to the Republic, Part II," The North American Review, 130 (May 1880 ); George Ticknor Curtis, "McClellan's Last Service to the Republic, Part III," The North American Review, 130 (May 1880); James Havelock Campbell, McClellan: a Vindication of the Military Career of General George B. McClellan: A Lawyer's Brief (New York: Neale Publishing Company, 1916). For a modern review of McClellan's Own Story see Stephen W. Sears' "The Curious Case of General McClellan's Memoirs," Civil War History, 34 (June 1988). 
only a small portion of the entire biography, Prime filled these pages with the type of allegorical stories typical of hagiographies. In this example, Prime moved from the early years of McClellan's life to the conflict, which to the author is denoted as McClellan's finest hour.

Upon the outbreak of hostilities in 1861, Prime detailed what McClellan left behind in order to become the commander of the militia in Ohio. Prime expressed his amazement that McClellan would commit such a sacrifice, by giving up his happy home with a loving wife and a large income to join the cause of the Union. ${ }^{5}$ This perspective is interesting since McClellan neither lost limb nor life during the conflict. Prime continued the biographical sketch by assaulting all who stood in McClellan's way. The author made the irrational leap that if McClellan and President Lincoln would have had their way, the war would have been over by the summer of 1862 had it not been for the Radical Republicans. ${ }^{6}$ Interestingly, Prime does concede that McClellan had his faults, namely that he was slow to see the evil in other men; thus, creating an image of piety and honesty for McClellan and the opposite for his opponents. ${ }^{7}$

Prime continues the assault on the politicians while discussing McClellan's 1862 Peninsula Campaign. After McClellan sent a telegraph message accusing the Lincoln administration, and particularly Secretary of War Edwin Stanton, of sacrificing the Army of the Potomac for political gain, Prime explained that since Stanton did not react to the message with righteous indignation, then McClellan's assumptions must be true. ${ }^{8}$ Prime's use of the null argument, that something must be true if no one counters that

\footnotetext{
${ }^{5}$ Ibid., 2.

${ }^{6}$ Ibid., 4.

${ }^{7}$ Ibid.

${ }^{8}$ Ibid., 10.
} 
argument, is both ignorant and laughable. The author also comes to the defense of McClellan when discussing the 1862 siege of Yorktown. Instead of the siege being a slow and deliberate process, Prime remarks that the siege at Yorktown was one of the fastest sieges in history. ${ }^{9}$ This assertion is yet another example of the revisionist history conducted by McClellan's admirer.

Prime does not stop with the Peninsula Campaign. He continued his laudatory praise for McClellan throughout the rest of the general's command of the Army of the Potomac. One of the ways the author conveyed the saintly stature of McClellan was through the use of allegories. Prime describes a tale that revolved around a young Irish housemaid who had come to Antietam to find the grave of her brother. According to the tale, the housemaid wandered the battlefield heartbroken over being unable to find her brother. A man appeared on a magnificent horse and asked what troubled her. Upon hearing the young woman's tale, the man first explained to the woman not to be heartbroken since her brother had died as a true soldier. He then ordered one of the orderlies on the battlefield to help the woman find her brother and departed the scene. The young Irish lass found her brother and asked the orderly who the man on the horse was. The orderly responded that it was "Little Mac," to which the woman replied "God Bless Him." "The story painted McClellan as someone who is larger than life, as well as a character that seems to be otherworldly. It does not matter if the story is true, and evidence point to it not being so, it only matters that Prime painted McClellan in the best possible light.

Prime concluded the biographical sketch portion by describing how he assembled

\footnotetext{
${ }^{9}$ Ibid., 12.

${ }^{10}$ Ibid., 19.
} 
the book. He explained that he came into various manuscripts that McClellan had written and that McClellan's wife had granted him access to much of the general's private correspondence. Prime ended by declaring that the biography was for the fellow-citizens that honored him and the soldiers that loved him and that he hopes that McClellan will be happy with him when they meet again. ${ }^{11}$ Throughout the biographical sketch, Prime described George B. McClellan as a man that was head and shoulders above his contemporaries. Although this type of hagiographic prose was true of many of the biographies that were commonplace throughout this time period, with the possible exception of Peter S. Michie's 1901 General McClellan, hagiographies have no place in a scholarly discussion except as historiography. ${ }^{12}$ It is understood that hagiographies are part of the landscape, but academic scholars and general readers, understand that such uses of biography detracts instead of adds to the history of the subject.

\section{Post-World War II and the Emergence of T. Harry Williams}

One man dominates post-World War II historiography of General McClellan, T. Harry Williams. Although he was not the only author who would capture the essence of McClellan during the time period, Williams' work announced a new phase of examination into the life and decisions of McClellan. Williams' seminal 1952 book, Lincoln and His Generals ushered in new thoughts on McClellan; even as authors such as Warren W. Hassler in his 1957 book General George B. McClellan: Shield of the Union

\footnotetext{
${ }^{11}$ Ibid., 22-23.

${ }^{12}$ Peter S. Michie, General McClellan (New York: D. Appleton and Company, 1901). Michie's biography is a different look on General McClellan. Michie does not believe that McClellan was the best commander for the Army of the Potomac and that the General displayed an unnerving lack of courage during the campaigns that he commanded.
} 
continued to make the case that McClellan was one of the great generals of the war. ${ }^{13}$ While Hassler and authors of his kind turned towards the hagiographical narratives of an earlier time, Williams moved the historiography forward. The change of scholarly practice first started by Williams exists into the modern scholarship.

During the 1950 s T. Harry Williams never wrote an essay or biography that focused exclusively on McClellan. Instead, he chose to analyze McClellan within the confines of the relationships that he developed or destroyed during the Civil War, and Lincoln and His Generals is one such examination. Williams described the traits and characteristics that made McClellan the general that he was. Although Williams conceded that McClellan was a great organizer of men and a fine trainer of troops, when he got into the field he became timid and over-cautious. McClellan was unable to interpret what the sights and sounds of the battlefield meant to his army. He was unable or unwilling to commit to a grand maneuver that would mean victory or defeat, and he lost the initiative to fight when bolder commanders brought the battle to him. He had a great mind when it came to the strategic portion of the war, but dealing with the tactical decisions while on campaign proved the downfall for McClellan. ${ }^{14}$ Williams also believed that had McClellan had a few humbling experiences while rising to the top rank, he would have been able to make the decisions necessary for a successful conclusion to the campaigns. ${ }^{15}$ Instead, McClellan was thrown into the top position of the Army by President Lincoln without first understanding the intricacies of conducting a wartime

\footnotetext{
${ }^{13}$ T. Harry Williams, Lincoln and His Generals (New York: Knopf, 1952). Warren W. Hassler, General George B. McClellan: Shield of the Union, (Baton Rouge: Louisiana State University Press, 1957.

${ }^{14}$ Williams, Lincoln and His Generals, 27.

${ }^{15}$ Ibid., 26.
} 
campaign while balancing political realities.

But to T. Harry Williams, those defects were not the overriding cause for the unsuccessful command of General McClellan. Two other factors existed that were above all the others. The first was the arrogance that McClellan possessed during his tenure. ${ }^{16}$ Williams understands that a number of the officers whose arrogance did them few favors on the battlefield, but those men were not the General-in-Chief and Commander of the Army of the Potomac. The second was the separate reality that McClellan lived in during his tenure as commander. Williams related that McClellan wanted to stage a great sweeping movement into the Confederacy with the sum total of all the soldiers that could be mustered for the Union cause. ${ }^{17}$ All other departments would be stripped bare of their forces in order to accommodate McClellan's desired drive towards Richmond. This strategy was unsound for two distinct reasons. First, it diminished the fighting force already engaged with Confederate forces in the other departments and second it turned the aim of the war from the destruction of the Confederate army to the capture of Southern cities. ${ }^{18}$ While the capture of Southern cities, and in particular Richmond, was a noble goal, it was not the end game. In order to crush the Confederacy, the Union Army must destroy the Confederate Army no matter where it resided. In other words, the Union forces should have moved on a city only if it was known that the Confederate Army is located within that city. According to Williams, McClellan never learned that lesson. ${ }^{19}$ He took places time and time again with little thought of whether the taking of the city or town would further the war aims of the Union.

\footnotetext{
${ }^{16}$ Ibid., 28.

17 Ibid., 30-31.

18 Ibid., 31.

${ }^{19}$ Ibid., 31.
} 
Warren W. Hassler's 1957 General George B. McClellan: Shield of the Union offered a different perspective on McClellan. In this book, Hassler defended the choices made by McClellan during the Peninsula Campaign and the battle of Antietam. While Williams believed that the Peninsula Campaign was a disaster that could have been easily been turned into a triumph, Hassler believed that the campaign was a masterful tactical retreat. ${ }^{20}$ Like previous authors of McClellan hagiographies, Hassler placed much of the blame for the unsuccessful campaign on the politicians in Washington, most notably Secretary of War Edwin Stanton. Hassler described how Stanton pulled troops away from McClellan's army on Abraham Lincoln's orders by making the excuse that these troops were needed in the defense of Washington. Hassler emphasized Stanton's disdain for McClellan, painting a picture that the Secretary of War wanted McClellan to fail during the campaign. ${ }^{21}$ Hassler reviewed the decision by Stanton to stop all recruiting in the North. Again Hassler deemed this decision to be another assault on the general from the politicians in Washington. ${ }^{22}$

According to Hassler, the politicians in Washington were not the only problem that confronted McClellan during the Peninsula Campaign. He also had to contend with the weather. The author explains that the roads in Virginia during the rainy season were bad enough when the Confederates first traversed them, but the roads were a quagmire for the Federals as they pursued the retreating army. ${ }^{23}$ Those roads made for slow going

\footnotetext{
${ }^{20}$ Hassler, General George B. McClellan, 142-171. In these pages, Hassler reviews in great detail the tactical withdrawal led by General McClellan. At no point does Hassler concede that the Union Army had an opportunity to push through the Confederate lines near Richmond in order to affect a rout within the lines.

${ }^{21}$ Ibid., 81-82.

${ }^{22}$ Ibid., 86.

${ }^{23}$ Ibid., 97.
} 
for the Union Army and allowed the Confederates to set up defensive works to combat the Federals. But even as the roads allowed for slow transport, Hassler commented on how fast McClellan got to the battlefield at Williamsburg astride his famous horse Dan Webster, leaving his staff far behind. ${ }^{24}$ Nothing could stop the great McClellan from reaching the front and his trusted soldiers.

McClellan's role in the defense of Washington and the Maryland Campaign also play prominent roles in Hassler's book. Hassler explains that after the Union defeat at the battle of Second Bull Run in 1862, the Union Army was in disarray and the politicians in Washington were concerned for their safety. Lincoln and Stanton visited McClellan and asked him to personally take charge of all the troops in Washington in order to lead an effective defense. ${ }^{25}$ McClellan set about meeting the troops on their way back to Washington to give them the boost of morale they so badly needed. Here, Hassler describes the scene from his point of view:

Men rubbed their eyes in wonderment. Could it be possible? It looked like McClellan, 'our George,' but that was inconceivable! Yet there he was, once more at their head. He had no insults for them, as Pope had had: he had only praise and a word or two of encouragement. ${ }^{26}$

Thus the scene was set, a savior had once more come to Washington to snatch victory from the clutches of defeat. Although he knew that a lot of hard fighting was left to be done, Hassler noted that McClellan felt confident that he could save the capital. ${ }^{27}$ But just as McClellan prepared to take the mantle as Commander of the Army of the Potomac once again, the radical politicians of Washington used McClellan as a scapegoat for the

\footnotetext{
${ }^{24}$ Ibid., 101.

25 Ibid., 224.

${ }^{26}$ Ibid., 228.

27 Ibid.
} 
disaster at Second Bull Run. ${ }^{28}$

After the defense of Washington was complete, McClellan's next order of business was to combat the Confederate forces who had invaded Maryland. On September 13,1862 , McClellan caught a lucky break early in the campaign with the discovery of the famous "Lost Order" that detailed the movements of General Robert E. Lee's forces. McClellan used this order to set up a battle that was on ground of his choosing, Antietam. Unfortunately, McClellan failed to take advantage of the numerical advantage that he enjoyed. Instead of leading a concerted attack against the whole of the Confederate line, he elected to send in piecemeal attacks against various portions of the line. Other historians have put the impetus on McClellan for this decision, but Hassler believes that it was the corps commanders who made the mistake of sending in piecemeal attacks. Instead, Hassler noted that McClellan wanted all the corps commanders to work together in one concerted effort, but the aggressiveness of the commanders became a liability. ${ }^{29}$ But, according to Hassler, the most egregious error committed that day was by General Ambrose Burnside. Hassler remarked that if Burnside had listened to McClellan and attacked at first light instead of early in the afternoon, McClellan's grand plan of decimating the Confederate Army would have come to true. ${ }^{30}$ Yet again, it was not the fault of General McClellan that the Union Army failed to destroy the Confederate Army.

\section{McClellan and the Social Historians}

Social historians came into the fore in the early 1960s. These historians not only examined the public and private lives of famous and influential figures, but also the lives

\footnotetext{
28 Ibid., 229.

29 Ibid., 285.

${ }^{30}$ Ibid., 285-289.
} 
of the common man. Although the historiography of McClellan contains some social historians, for the most part the writers of this period continued to focus on McClellan as a commander. Some social historians used McClellan's followers within the ranks of common soldiers as an example of a personality cult. Others examined McClellan through a more critical lens to extract the essence of McClellan. Historian Bruce Catton wrote a three part series on the Army of the Potomac in the 1960s, focusing primarily on McClellan's command in his first volume. While Catton does discuss McClellan on various occasions, Catton is more interested in the Army of the Potomac as an institution.

Bruce Catton's 1962 The Army of the Potomac: Mr. Lincoln's Army explained the Army of the Potomac from its inception in 1861 to McClellan's departure in November $1862 .{ }^{31}$ Although it was an institutional perspective on the Army of the Potomac, Catton's insights on both the leaders and the everyday soldiery are interesting. Since this book was devoted to the Army of the Potomac, it can be expected that McClellan would be treated rather well since he was the one that started the Army of the Potomac. Throughout the book Catton offered explanations for McClellan's behaviors, even going as far as to say that the boasts McClellan were making about saving the Union were true, and that he was the only one that could do so. He offered as his impetus for this statement that the citizens of the Union did call for him to save them and that he understood what the main reasons for the failures of the Union during the war. ${ }^{32}$ But

\footnotetext{
${ }^{31}$ Bruce Catton, The Army of the Potomac: Mr. Lincoln's Army (Garden City, New York: Doubleday \& Company, 1962). For further reading from Social Historians during this time please see Edwin C. Fishel, "The Mythology of Civil War Intelligence," Civil War History, 10 (December 1964). Harsh, "On the McClellan-Go-Round," Civil War History, 19 (June 1973) .

${ }^{32}$ Ibid., 61 .
} 
Catton also conceded that McClellan was prone to fits of slowness, mostly because McClellan did not want to move in any direction that may lead to a bloody disaster for his men. ${ }^{33}$ This concession does not mean that he believes there is a man better suited for the job. Catton was especially venomous towards General Henry Halleck, the man who took over the position of General-in-Chief from McClellan. Catton insinuates that Halleck could never make a decision for himself and calls him "a typical old-line government-service hack." 34 For Catton, McClellan held a special place because he was the founder of the Army of the Potomac. The politicians and political officers appointed to places of command within the army were the real enemy. Catton believed, just as historians had previously, that McClellan would have been more successful if the politicians would have stayed out of the running of the war and allowed a man with a superior military mind deal with the Confederacy. In reality, The Army of the Potomac: Mr. Lincoln's Army pays homage to the men that served in that army. Although the book focuses on McClellan and his contemporaries, it also analyzes the lives of those soldiers affected by the decisions that were made by their leaders.

\section{Stephen Sears and Modern Historians}

In 1988, Stephen Sears published George B. McClellan: The Young Napoleon, the first true analytic and comprehensive biography of the general. ${ }^{35}$ Shortly after in 1989 , Sears compiled a book of McClellan's papers from the Civil War era entitled The Civil War Papers of George B. McClellan: Selected Correspondence, 1860-1865. ${ }^{36}$ This

${ }^{33}$ Ibid., 5.

${ }^{34}$ Ibid., $5,197$.

${ }^{35}$ Sears, The Young Napoleon.

${ }^{36}$ Stephen W. Sears ed., The Civil War Papers of George B. McClellan: Selected Correspondence, 1860-1865 (New York: Ticknor and Fields, 1989). A selected list of 
collection of personal and professional correspondence was a breakthrough for the scholarship of George B. McClellan. Several authors used Sears' work and a new interest in McClellan arose. Among these authors were such historians as Joseph Glatthaar, who used the correspondence as a starting point for discussing the mental capacity of General McClellan. Another example is Thomas J. Rowland, who used the correspondence to reinforce the idea that McClellan was being beset from all sides. Although each of the authors took a very different view of McClellan, it is quite clear that each examined in depth Sears' biography and selected correspondence to couch their examinations of McClellan. Because of his work in the field, Sears stands as a prominent figure in the modern historiography of General George McClellan.

By itself, Sears' George B. McClellan: The Young Napoleon is not a groundbreaking biography. It is just a normal biography that makes no great criticisms or acclaim for McClellan. Instead, Sears presented the general and allowed the reader to form their own opinions. But if the book was unspectacular, the topic of it was the opposite. Since this book was the first comprehensive biography of McClellan to take into account his personal and professional life, it was in uncharted territory. Sears could have made the type of remarks that earlier historians had, whether they be of the hagiographic nature or the overly critical nature. Sears chose to do neither of these. It was this decision that led to so much interest in the life of McClellan. If Sears would have made outrageous claims about McClellan, whether they were negative or positive,

some of the authors who used Sears' work includes Ethan S. Rafuse, McClellan's War: The Failure of Moderation in the Struggle for the Union (Bloomington: University of Indiana Press, 2005). Edward H. Bonekemper, McClellan and Failure: A Study of Civil War Fear, Incompetence, and Worse (Jefferson, NC: McFarland and Company, 2007). John C. Waugh, Lincoln and McClellan: The Troubled Partnership Between a President and His General (New York: Palgrave Macmillan, 2010). 
his work would not have been taken as seriously as it was. Instead, it was the launching point for every scholar or writer since its publication that attempted to understand McClellan on a greater scale. One such writer that sought a greater understanding of McClellan was Joseph Glatthaar.

Joseph Glatthaar's 1994 Partners in Command: The Relationships Between Civil War Leaders in the Civil War, explained why some partnerships during the Civil War worked and others did not. ${ }^{37}$ Although Glatthaar spent a majority of the book discussing the partnerships of such duos as General Ulysses S. Grant and General William T. Sherman and General Robert E. Lee and General Thomas "Stonewall" Jackson, the most useful portion of the book is the appendix. In this appendix, entitled "McClellan's Tragic Flaws in the Light of Modern Psychology," Glatthaar concluded that McClellan was afflicted with a paranoid personality disorder which tended to manifest itself into narcissistic tendencies. ${ }^{38}$ According to Glatthaar, mistrust lies at the center of a paranoid personality disorder and the afflicted will question the loyalty of others with little or no cause. $^{39}$ Also, Glatthaar concluded, those afflicted have a need to dominate those around them and feel that those who question them are inferior in some way. ${ }^{40}$ Also, people with this disorder seem to be calm and rational to those around them, but when a new problem or unexpected event blocks their path, they block out all new information that runs contrary to what they originally believed.

Glathaar then explains what events in McClellan's life were examples of this type

\footnotetext{
${ }^{37}$ Joseph T. Glatthaar, Partners in Command: The Relationships Between Civil War Leaders in the Civil War (New York: The Free Press, 1994).

38 Ibid., 237-238.

${ }^{39}$ Ibid., 237.

${ }^{40}$ Ibid., 238.
} 
of disorder. The author states that the signs of his disorder began early in his life. At the age of twelve, McClellan and his teacher Reverend Samuel Crawford had an argument that McClellan claimed fifty years later was not his fault. ${ }^{41}$ Whenever he was put under a superior, according to Glatthaar, McClellan squabbled with that superior. ${ }^{42}$ The constant need to argue with superiors was the reason that the relationship between President Abraham Lincoln and General George McClellan crumbled. McClellan's extreme secrecy in his plans and the imagined slights from the president and his cabinet put further strain on the relationship. ${ }^{43}$ He was critical of all members of the cabinet and the president himself, but he could not take the slightest criticism from others. ${ }^{44}$ Glatthaar concluded, that with the combination of these traits, McClellan failed to perform with any success his duties as both the General-in-Chief and the Commander of the Army of the Potomac. ${ }^{45}$ Glatthaar's examination of the psychology of McClellan opened the door for other historians to examine the personality traits of other historical figures.

Thomas J. Rowland's 1998 George B. McClellan and Civil War History: In the Shadow of Grant and Sherman is a throwback to the time of the McClellan hagiography. ${ }^{46}$ Like many of the earlier authors, Rowland decries how the politicians block every move that McClellan makes. Interestingly he places part of the blame on President Abraham Lincoln. Rowland explained that since a commander has to take some of the blame for his subordinates, the President must take some of the blame for his

\footnotetext{
${ }^{41}$ Ibid., 240.

42 Ibid., 241.

${ }^{43}$ Ibid., 242.

${ }^{44}$ Ibid.

${ }^{45}$ Ibid.

${ }^{46}$ Thomas J. Rowland, George B. McClellan and Civil War History: In the Shadow of Grant and Sherman (Kent, OH: Kent State University Press, 1998).
} 
cabinet. $^{47}$ The person that Rowland believed the president should be blamed for is obviously Secretary of War Edwin Stanton. Rowland concluded that Stanton tricked McClellan into making bad character judgments about the president when it was Stanton himself that did not like McClellan. ${ }^{48}$ In regards to the relationship between McClellan and Stanton, Rowland rehashed ideas that have been floating around the pro-McClellan camp for well over a century. Interestingly, Rowland takes the opposite opinion about the share of blame when it comes to McClellan. He says that a commander cannot be held responsible for what his subordinates do if the commander gave them orders. ${ }^{49}$

Rowland created a new dimension to the hagiography of General McClellan; not by just building up McClellan to mythical proportions, but to tear down all others to his level. For example, if McClellan was crazy, than Sherman was crazier; McClellan may have been gruff, but he was not as malevolent as General Joseph Hooker. ${ }^{50}$ Rowland also criticized Grant and Sherman, establishing the fact that they had many more difficulties during the first part of the war than McClellan. But the difficulties that the author described are the same type of difficulties that he explained away for McClellan, the difficulties were with the subordinate commanders, not Sherman and Grant themselves. ${ }^{51}$ Thomas Rowland can be summed up sby his argument that,

Throughout the first year of the war, McClellan's strategy was innovative, appropriate, and even brilliant in many respects. The amassing of overwhelming military force, directed along the correct lines of maneuver and brought to a selected battlefield, was both militarily sound and

\footnotetext{
${ }^{47}$ Ibid., 50.

${ }^{48}$ Ibid., 51 .

${ }^{49}$ Ibid., 66-67.

50 Ibid., 54.

${ }^{51}$ Ibid., 67.
} 
politically attuned to the national strategy. He was not an idiosyncratic doctrinaire. ${ }^{52}$

Rowland's dedication to McClellan did not allow him to see the faults that the evidence pertaining to McClellan has unearthed. Although Rowland attempted to show that McClellan was not at fault for his failures, Rowland's point gets lost in the hagiographical nature of his scholarship.

Throughout the years, the historiography of General George B. McClellan has changed considerably. Starting in the years following the Civil War, various authors offered hagiographical biographies dedicated to McClellan. After World War II, historians began to take a more critical look at the first Commander of the Army of the Potomac, especially T. Harry Williams, but others like Warren Hassler held on to the traditional thought that McClellan was one of the great generals of the war. In the early 1960s, social history came to the fore, as historians began in earnest to look at all aspects of the war. However, some scholars such as Bruce Catton continued to cast George McClellan in a good light, even if the historical evidence pointed to the contrary. After the release of Sears' George B. McClellan: The Young Napoleon in 1988 and the 1989 release of Sears' The Civil War Papers of General George B. McClellan: Selected Correspondences, 1860-1865, a renewed interest in McClellan began to multiply. With this interest came new approaches to looking at the scholarship such as the examination of the possible personality disorders of George McClellan by Joseph Glatthaar. Supporters of McClellan can still be found in the modern age as noted by Thomas Rowland's refutation of Glatthaar's theories in his book George B. McClellan and Civil War History: In the Shadow of Grant and Sherman. Although authors in the current

${ }^{52}$ Ibid., 96. 
decade have varied views on McClellan, it is safe to say that the mystery that is General George B. McClellan will be debated for the foreseeable future. 


\section{CHAPTER III}

\section{MCCLELLAN AND HIS HISTORICAL MOMENT}

A commander needs many attributes if they are to get to the top of the military hierarchy. A commender needs to handle troops when orders have fallen into disarray. They must instill the confidence in their men so that his orders are not disobeyed. They need ambition to make sure that the troops under their command become the best fighting unit possible. But, a commander also requires luck. They need for all the pieces to fall into place so that they can move further up the military chain-of-command. For Major General George B. McClellan, the pieces fell into place early on in his career as a commander during the Civil War. Some of the pieces were of his own making while others such as timing and the Union's lack of high-ranking military commanders were out of his hands. General McClellan used these opportunities to further his military aims, both for himself and for his army, which had become an extension of him. Although McClellan showed a lack of regard for the military rules, at the time, his superiors in both the military and the civilian sectors viewed him as the logical answer to the question of who would run the Union's army.

McClellan had already won victories in western Virginia, although not as singlehandedly as he would have the politicians and media believe. He also trained, supplied, and shaped troops from Ohio, Illinois, and Indiana into an effective fighting force. It was no small task to transform the volunteers into soldiers, and McClellan made 
sure that those in higher positions of power, especially General Scott, Secretary of War Salmon Chase and President Abraham Lincoln, understood the great effort that the undertaking of creating such a force entailed. It was the call to come to Washington that set McClellan's trajectory. He was no longer the commander of a force of volunteers in the West. Instead, he became commander of an army in the Eastern Theater; an army that he created from nothing, the Army of the Potomac.

But trouble built for General McClellan as politicians began to murmur about the slowness of his campaigns. Thankfully for McClellan President Abraham Lincoln stood by him and fended off many of the attacks levied at the general. Historians have considered the question of why President Lincoln stood by McClellan even after it had become obvious that the general was not up to the task of commanding an army. The answer lies in the historic moment. This chapter examines the rise and fall of General George McClellan through the prism of his historical moment. This chapter analyzes what officers were available to the Union cause at the beginning of the Civil War and why the Union was willing to bring an young and untested general on as the commander of their entire eastern forces. The chapter also delves into why such famed generals of the end of the Civil War were not considered for the post, most notably Ulysses S. Grant and William T. Sherman. Finally, this chapter examines the fall of McClellan and why President Lincoln so abruptly put an end to General McClellan's command.

\section{McClellan's Rise}

General George McClellan's rise to the top of the military chain of command was not a coincidence of fate. In 1846 General McClellan finished second in his class at the United States Military Academy at West Point and upon graduation went off to fight in 
the 1846-1848 Mexican War. In that conflict he received two brevets for his bravery during the war and participated in many of the battles of the war including Vera Cruz, Cerro Gordo, and Mexico City. These experiences led to the Army taking an interest in McClellan and after the war, the Army sent McClellan to the Crime in 1855, by then Secretary of War Jefferson Davis, with two other officers, Majors Richard Delafield and Alfred Mordecai, to observe the Crimean War between Russia and France. ${ }^{53}$ In 1856, upon his return to the United States after the six-month mission to Europe, McClellan resigned from the army and took up a post as a Vice President for the Illinois Central Railroad. He worked in the civilian sector, but he kept a close eye on the emerging hostilities between the southern states and the federal government. McClellan's knowledge in both military and civilian matters would enable him to use those skills while in pursuit of a commander's position.

On April 12, 1861 when hostilities broke out between the seceded states and the federal government at Fort Sumter in Charleston harbor, McClellan contacted governors from both Pennsylvania and Ohio and requested to join their volunteer forces. In April 1861 because of his training at West Point, past involvement in the Mexican War and his background as an engineer, Ohio Governor William Dennison appointed McClellan as commander of the Ohio volunteers. In May 1861, McClellan parlayed the post into a Major General appointment in the Union Army as the Commander of the Department of the Ohio in May 1861. This quick ascension to the command level left many scholars baffled by the speed in which General McClellan obtained the post. The question of why he rose so fast in the ranks can be answered in part by analyzing the cadet rolls from the

\footnotetext{
${ }^{53}$ Stephen W. Sears, George B. McClellan: The Young Napoleon (New York: Da Capo Press, 1988), 44.
} 
United States Military Academy.

The cadet rolls from West Point illuminate one factor of why General McClellan rose so quickly, and, why ironically, his fall from command was just as rapid. By researching the three classes before McClellan's class, General McClellan's 1846 class itself, and the three succeeding classes, an interesting theme emerged -- the lack of officers fit for duty when the Civil War began. The total number of graduates at the United States Military Academy for these seven classes was 283 total cadets. ${ }^{54}$ Of those 283 cadets, 105 of them had died, resigned, or were dismissed before the Civil War. ${ }^{55}$ Of the final 178 cadets left at the outbreak of hostilities, a further forty-seven resigned their commissions to become officers in the Confederate States Army (CSA). ${ }^{56}$ Out of a possible 283 cadets that could have been used by the Union during the Civil War, only 131 officers from these seven classes took part in the Civil War on the Union side. By examining the rolls from an earlier era, specifically Robert E. Lee's 1829 graduating class and the class preceding it, this loss in officers was even more apparent. The two classes combined had a total of seventy-nine graduates. ${ }^{57}$ Of those cadets, fifty-six had died, resigned, or were dismissed before the outbreak of the Civil War. A further eight left the Union army to join the CSA upon the assumption of hostilities, including Robert E. Lee, whom many considered as the best officer to come through West Point. ${ }^{58}$ Out of a possible seventy-nine candidates for positions within the Union Army from the 1828

\footnotetext{
${ }^{54}$ Association of Graduates, USMA, Register of Graduates and Former Cadets of the United States Military Academy: Cullum Memorial Edition (Crawfordsville, IN: R. R. Donnelley and Sons Company, 1980), 236-242.

${ }^{55}$ Ibid.

${ }^{56}$ Ibid.

${ }^{57}$ Ibid., 224-225.

${ }^{58}$ Ibid.
} 
and 1829 classes only fifteen were still in the military at the beginning of the Civil War. The loss of those men from the earlier classes, men that would at the beginning of the Civil War be destined for leadership roles within the Union Army, hurt the leadership structure of the United States military the most. Men from later classes, men like McClellan, moved into the leadership roles that had been vacated by those that left the army. By extrapolation, approximately fifty to sixty percent of the graduates of West Point were not actively involved with the Union cause at the beginning of the war. Because of this low number of officers, a smaller pool of officers to pull from in regards to leadership positions within the army existed. Because McClellan had shown himself to be a capable engineer and officer and the lack of available other candidates, McClellan moved swiftly up the ranks even though he left the army in 1856 at the rank of Captain.

The numbers from the graduating classes of West Point do not tell the whole story. The men who led the Union to victory after four years of hard fighting in 1865 also came from West Point and decided to stay with the Union when the South seceded. If those men stayed within the Union Army during the Civil War, the question that needs to be addressed was why did they not get an opportunity to lead before the mantle fell to George McClellan. One reason for this issue was the dynamics of the United States Army before the Civil War. Before the war, the army was a small enterprise with little in the form of upward mobility for career officers. It was not unusual for an officer to spend his entire career in the army and only obtain the rank of Major. For this reason many officers that would have been at the fore of the army at the start of the war were still in the process of moving up the ranks. The lack of advancement seen before and during the Civil War is different from the armies in World War I, World War II, and subsequent 
contemporary military conflicts. An extreme case of men staying at the top of the American military forces was General Winfield Scott. Scott was the General-in-Chief of the army at the beginning of hostilities, a man who had seen action in the War of 1812 and had obtained the rank of Brigadier General during that conflict. General Scott's military career spanned 47 years, from the War of 1812 to the Mexican War and on to the Civil War. The longevity of his career would be unheard of in today's military, but the leaders of the United States military of the nineteenth century believed in having a small force, composed of volunteers who fought only during the conflict and then returned home, directed by a larger officer corps. Because of the larger officer corps and the decided lack of movement to higher ranks many officers chose to leave the military profession.

The officers who chose to stay within the military profession and who outranked General McClellan at the start of the war were scattered throughout the United States. Most officers of the United States Army were already in jobs needed by the country. Some worked as quartermasters and engineers while others commanded corps and brigades. McClellan's decision to join a group of volunteers instead of re-entering the army at his old rank allowed him to move ahead of many officers who would have outranked him. When McClellan became the Major General of the Ohio Volunteers and was subsequently given the commandership of the Department of the Ohio, the military had little choice but to award him the same rank as he had held while he was with the men from Ohio. In essence, General McClellan went from the rank of Captain to the rank of Major General by job choice and subtle maneuvering. Although McClellan remarked that he took the position of Major General in Ohio because he wanted to help 
the Union in any way that he could, he must have known that he had positioned himself into a greater position once the United States military asked for his services. General McClellan was not unlike many of the other officers who used political methods, either by petitioning governors or raising a certain number of troops, to gain access to higher ranks.

Generals Ulysses S. Grant and William T. Sherman were prime examples of two officers that would, later in the war, turn the fortunes of the Union, but whom the Army passed over for General McClellan. Both of these generals served on active duty during the early stages of the outbreak of hostilities, but they were in not in positions of power. At the beginning of the war General Grant was, like General McClellan, in the civilian sector. At the outbreak of hostilities in April 1861, Grant lived in Galena, Illinois working at a leather goods shop. The populace of Galena called on General Grant to hold a meeting to discuss what steps needed to be taken as he was the only military professional in the area. During that meeting, it was declared that General Grant would lead the effort to recruit new volunteers and take them to the capital of Illinois, Springfield. $^{59}$ While in Springfield, Illinois Governor Richard Yates asked Grant to help lead and train the volunteers from the state. ${ }^{60}$ While Grant helped to recruit and train the

${ }^{59}$ Ulysses S. Grant, Personal Memoirs of U.S. Grant (Lincoln: University of Nebraska Press, 1996), 139. Ulysses S. Grant is used as an example of an officer that made a large impact during the later stages of the Civil War, but was not in a position to counter the rise of General McClellan. Since General Grant is not the prime subject of this essay, if the reader would like further analysis of General Grant during the Civil War, please see Adam Badeau, Military History of Ulysses S. Grant, from April 1861, to April 186, (New York: D. Appleton, 1881); Bruce Catton, U.S. Grant and the American Military Tradition (Boston: Little, Brown, 1954); Brooks D. Simpson, Ulysses S. Grant: Triumph over Adversity, 1822-1865 (New York: Houghton-Mifflin, 2000) and William S. McFeely, Grant: A Biography (New York: Norton, 1981).

${ }^{60}$ Grant, Personal Memoirs, 140. 
volunteers of Illinois, he also hoped to gain an officership with the regular army. Grant sent a letter to the Adjunct-General of the United States Army, Colonel Lorenzo Thomas, tendering his services for use by the Army. ${ }^{61}$ Unfortunately for Grant, the letter never elicited a response from Colonel Thomas or anyone from the United States Army. Grant then traveled to Cincinnati in an effort to meet with General McClellan who was at the time the commander of the Department of the Ohio. Both men knew each other as they had both attended West Point at the same time. Grant called on McClellan on two successive days at his office, but did not meet with the General. ${ }^{62}$ By June 1861, having exhausted all avenues in an effort to join the regular Army, Grant accepted a promotion to Colonel by Governor Yates and was in charge of the unruly Twenty-first regiment of the Illinois Volunteers. ${ }^{63}$ At the end of August 1861, Major General John C. Fremont appointed Grant as the commander of the District of Cairo and Grant stayed in that position until February 1862. General Grant was in no position to challenge General McClellan for power. Instead, Grant used his time as a commander of volunteer forces to fine tune his fighting style. While McClellan was in the spotlight of the Eastern Theater where the media exposed every flaw, Grant failed on some of his campaigns, but had the opportunity to learn from his mistakes. Grant took the lessons learned from his earlier commands in the Civil War and introduced a strategic and tactical plan that, in time, ended the Civil War.

General William Tecumseh Sherman took a different road to generalship than did General Grant and in many respects moved with the same rapidity to the upper echelons

\footnotetext{
${ }^{61}$ Ibid., 143.

${ }^{62}$ Ibid.

${ }^{63}$ Ibid., 145.
} 
of the military hierarchy as General McClellan. Sherman moved up the ranks of the United States Army quickly, but he was not inclined to take any positions of leadership that left him with tough choices. Sherman's inability to make the tough choices in the end would be the reason that Generals Grant and Sherman made such a good team during the latter stages of the Civil War. General Sherman had also resigned his commission before the Civil War, in 1853, and worked in the private sector until the beginning of the Civil War. When hostilities broke out Sherman made the decision to rejoin the Union Army.

Congress commissioned Sherman, effective May 13,1861, as a colonel in the yet to be formed thirteenth United States Infantry regiment. ${ }^{64}$ Sherman fought in the First Battle of Bull Run and, on July 23, 1861 President Abraham Lincoln promoted him to Brigadier General with an effective date of May 17, 1861. In August 1861, the Army then assigned Sherman to General Robert Anderson's Department of the Cumberland located in Louisville, Kentucky. ${ }^{65}$ Unlike McClellan, Sherman did not seek the higher commands that came his way; instead, Sherman shied away from them, even at one point asking President Lincoln to not put him in a position that would have substantial

\footnotetext{
${ }^{64}$ William T. Sherman, Memoirs of General William T. Sherman (New York: Da Capo Press, 1984), 177. Since General Sherman is used as an example, like General Grant, of an officer that later made a difference during the Civil War, but was not in a position to counter the generalship claims of General McClellan, and is not the prime subject of this essay, the researcher did only nominal research on General Sherman and his position during the early stages of the Civil War. For further analysis on General Sherman and his activities during the war please see Cynthia Bass, Sherman's March, (New York: Villard Books, 1994); T. Harry Williams, McClellan, Sherman, and Grant (New Brunswick NJ: Rutgers University Press, 1962); and Charles Royster, William Tecumseh Sherman, Stonewall Jackson, and the Americans (New York: Knopf, 1991).

${ }^{65}$ Sherman, Memoirs of General William T. Sherman, 193.
} 
command responsibilities. ${ }^{66}$ In time the Army charged Sherman with the command of the Department of the Cumberland after General Anderson left in October 1861, by early November 1861 General Sherman a mental collapse and he asked to be relieved of command. At the time that Sherman commanded a regiment, McClellan was already on his way to Washington. When the Army selected Sherman as a Brigadier General, General McClellan had consolidated the forces that surrounded the capital into an army and had installed himself as commander. That force became the Army of the Potomac and survived until the end of the war as the main body of Union troops in the Eastern Theater of the war. With General Grant and General Sherman serving in the Western theater, they were not a threat to McClellan's rise to power. General Grant was too busy training troops for the Illinois' regiments and General Sherman had no inclination or ambition for command. Many more examples could be found that echo the careers of General Grant and General Sherman; McClellan was the exception and not the rule when it came to seeking generalships in the Union Army. Although President Lincoln appointed other political generals at the beginning of the Civil War, only McClellan moved with rapidity to the highest command in the Army. McClellan's experience, knowledge and intimacy with both moderate Democrats and conservative Republicans made him an ideal choice by the president as a commander.

\section{McClellan's Stay at the Top}

In July 1861 , upon orders from the Lincoln administration, General McClellan came to the nation's capital. In July 1861, the capital and the northern states reeled from the disaster of the First Battle of Bull Run. The timing of McClellan's successes in

${ }^{66}$ Ibid. 
western Virginia could not have been better for him. The press reported that he had trounced the Rebels in a key region, and by the time he made his way to Washington, the public and politicians within the federal government proclaimed him as a savior. McClellan believed that if he had wanted he could have become the dictator of the country, all he had to do was say the word. But McClellan was not alone at the top of the military hierarchy when he came to Washington. General Scott was still the General-inChief of all the Union's armies, and if McClellan was to stay at the top, he would have to make the old warrior resign.

Winfield Scott had been an officer with the United States Army for forty-seven years. He was physically unable to make his way to the warfront and he was better suited for the administrative tasks and overall war planning that filled most of his time in Washington. Finally, on November 1, 1861, McClellan used his leverage of being the hero of western Virginia to wrest control of the Army away from General Scott. ${ }^{67}$

As General Scott faded into the background and McClellan took command of all the armies at the federal government's disposal, politicians wondered about when McClellan would conduct the next great campaign against the Confederacy. Members of the administration felt that the delays from McClellan were unacceptable. Unfortunately, those members of the administration who had hoped for a quick end to the war once General McClellan became the General-in-Chief would be disappointed. During the late fall and early winter of 1861 , the general set timetables to go on the offensive that he was unable to fulfill, giving timelines of first a couple of days then to a couple of weeks. During those months the president along with members of his cabinet would stop by

${ }^{67}$ Sears, The Young Napoleon, 125. 
McClellan's headquarters unannounced in order to see how McClellan's war plans were progressing. McClellan was so deeply unhappy about the intrusions that the president made on him at both his headquarters and his home that McClellan began to refer to Lincoln as "the Gorilla." 68 The remarks made by McClellan during the early days of his command about President Lincoln did not affect the relationship that the president had with McClellan. In fact, the president understood the social limitations of the general and he also understood that if the general could win the war then all of the snubs and remarks could be suffered.

Unlike McClellan, President Lincoln separated his personal and professional feelings. By December 1861, even the president's patience began to wear thin when it came to McClellan. Lincoln could dismiss McClellan's abrasive and sometimes insolent attitude as long as the general moved forward with his campaign. By the first part of December 1861, members of the administration and members of Congress became concerned about the overall lack of activity from the Union forces. On December 10, 1861 Congress set up the Joint Committee on the Conduct of the War, led by Benjamin Wade, a radical Republican from the state of Ohio. ${ }^{69}$ Compounding the difficulties that McClellan had with the joint committee, he contracted typhoid fever on December 20, 1861 just three days from his appearance before the committee. ${ }^{70}$ This illness was the first instance of bad luck meshing with the historical moment. Until this episode, the historical context that surrounded McClellan were ones that fell in his favor; his quick

\footnotetext{
${ }^{68}$ McClellan to Mary Ellen McClellan, Washington DC, November 18, 1861, in The Civil War Papers of George B. McClellan: Selected Correspondence 1860-1865, ed. Stephen W. Sears (New York: Da Capo Press, 1989), 136.

${ }^{69}$ Sears, The Young Napoleon, 136.

${ }^{70}$ Waugh, Lincoln and McClellan, 59.
} 
rise can be attributed in some sense to the historical timing in which he made his decisions. The incidents that followed would not have the same tinge of luck to them as when he first started, although the president gave McClellan more opportunities to prove himself that many other generals.

In early 1862 , hard times had befallen the Union cause. The president understood that the public outcry was for an aggressive strategy throughout both theaters of the war and that little had been done since Lincoln gave General McClellan the position of General-in-Chief. Gone were the days that McClellan told President Lincoln that he could do it all; now, all that was left was a general in the throes of typhoid fever, unable to command the army that he had been entrusted to command. ${ }^{11}$ Lincoln called a meeting of McClellan's generals in order to speak with someone about the plans needed to win the war against the Confederacy since General McClellan was incapacitated. On January 12,1862 , when General McClellan heard the news that the president was meeting with his subordinates, the general summoned the strength to attend the meeting and laid out his new campaign to the president. ${ }^{72}$ The president invited McClellan back on the next day to explain his position on his campaign with members of the cabinet. On that day, McClellan refused to divulge his plans to the president and the cabinet because they were military plans and the fewer people that knew about it the better. McClellan advised that no commander would give away the plans to such an assembly since some of those in attendance are incompetent and others are unable to keep a secret. ${ }^{73}$ In fact, McClellan

\footnotetext{
${ }^{71}$ Ibid., 60.

${ }^{72}$ Ibid., 63.

${ }^{73}$ Ibid., 64.
} 
stated that if he disclosed his plans, "they would be in the New York Herald tomorrow.",74 In the later years of the war, President Lincoln stripped commanders of their command for smaller offences than this outburst. This episode constituted an example of the dire straits that the Union cause was in at the beginning of 1862 . The top commander had suggested openly that the president and cabinet members were either incompetent or unable to keep a secret that pertained to national security.

January 13,1862 was a day that saw General McClellan lambasting the president and the cabinet and also the selection of a new Secretary of War, Edwin Stanton. McClellan envisioned the selection as fortuitous. Stanton had been McClellan's closest supporter against the president and the members of Congress in opposition to the decisions made by McClellan. But, Stanton chose to forego the support for General McClellan and instead he forged an alliance with the members of the committee and echoed the frustrations that they felt toward the general. ${ }^{75}$ This tactical move by Stanton led to hard feelings by General McClellan. On February 27, 1862, an event occurred that turned Stanton from a supporter of McClellan in to a vehement critic. In the early stages of the war the Confederacy held positions both above and below Washington and did not allow the Union the use of the Baltimore and Ohio Railroad's direct link to the Ohio Valley. ${ }^{76}$ To combat this problem, McClellan sent canal boats linking Maryland with Virginia in order for his troops to cross the Potomac and occupy any strategic location. Unfortunately, the engineers employed by McClellan failed to measure the width of the locks the boats would traverse through and the locks turned out to be six inches too

\footnotetext{
${ }^{74}$ Rafuse, McClellan's War, 170.

${ }^{75}$ Ibid., 177.

${ }^{76}$ Waugh, Lincoln and McClellan, 73.
} 
narrow for the boats to pass through. ${ }^{77}$ The Army scrapped the entire operation. The decision to scrap the operation sent Edwin Stanton into a rage and he communicated to the president that he felt that McClellan had no intention to make any type of movements. ${ }^{78}$ This episode constituted the clean break between Stanton and McClellan; never again did Stanton support the general. Stanton wanted to the win the war and the way that he saw the war unfolding, the nation needed an aggressive commander in charge of its forces. Stanton saw none of those traits in McClellan and turned on the once favored general.

With the relationship between Stanton and McClellan severed, the president called in General McClellan to explain the need for more rapidity in his movements. Lincoln cautioned McClellan that the public was getting restless and that the quicker a campaign could be started, the better it would be for the nation. On March 11, 1862 President Lincoln relieved General McClellan of his General-in-Chief position as McClellan could not direct the other departments while he was in the field with the Army of the Potomac and moved Major General Henry Halleck into the position. ${ }^{79}$ General McClellan became only the Commander of the Army of the Potomac as he made his way with his troops from Washington down to the disembarkation point at the mouth of the James River to begin the 1862 Peninsula Campaign. The Peninsula Campaign, which lasted from the beginning of April 1862 until July 1, 1862, did not go according to the plans that McClellan had set forth. His army was too slow in moving on the defenses of the Confederates since McClellan believed that the Confederate troops stationed in and

\footnotetext{
${ }^{77}$ Ibid.

${ }^{78}$ Ibid.

${ }^{79}$ Sears, Young Napoleon, 164.
} 
around Richmond outnumbered him. McClellan's hesitation to move in force towards Richmond and instead to set up for an extended siege of Richmond allowed the Confederacy to reinforce their troops. The decision to delay sending forces into Richmond led to the Union forces tactically withdrawing over an extended amount of time back to their base at the head of the James River. This withdrawal became known as the Seven Days' Battles since the Confederacy seized on the opportunity to destroy the Union Army. Although the Army of the Potomac retreated back to the relative safety of their base, the press and politicians in Washington considered the Peninsula Campaign a disaster. In August 1862, after the tactical withdrawal by McClellan, Lincoln made the decision to send McClellan's troops to Major General John Pope and his Army of Virginia to bolster his troop numbers during the Northern Virginia Campaign. In essence, McClellan became a commander without an army. With no army to command, McClellan undermined General Pope at all turns due to both personal conflict and a conflict over military thinking between the two. McClellan believed that to win the war the Army must outmaneuver their opponents, while Pope believed in sending his troops on frontal assaults. They also had political differences; McClellan believed that the Confederacy should be brought back into the Union with no punishment whereas Pope felt that the Confederacy deserved punishment for seceding from the Union. Some scholars, such as historian Evan Rafuse, insinuate that General McClellan held off sending troops to Pope until after the August 28-30, 1862 Second Battle of Bull Run was in doubt, as a way to compromise Pope's ability to gain a victory that the administration needed so badly in order to vindicate McClellan's new operational objectives. ${ }^{80}$

${ }^{80}$ Rafuse, McClellan's War, 259. 
Confederate forces soundly defeated the Union forces under General Pope at the Second Battle of Bull Run. In that defeat, McClellan felt justified for the way he had conducted the war because he had never been thoroughly defeated on the field of battle.

General John Pope's defeat put the administration in Washington on high alert. Politicians became concerned about the Confederate army attacking and taking the capital. The president called on McClellan to take command of all of the fortifications around Washington and, on September 2, 1862, McClellan assumed command. ${ }^{81}$ Later that same day, General Pope approached the outer reaches of the Washington defenses where he was told by General McClellan, in less than restrained happiness that he, McClellan, was in command of all the forces within the fortifications of Washington and Pope would no longer be needed. ${ }^{82}$

The question that must be asked was why Lincoln gave McClellan another chance with a large force of troops if it was obvious that he could not conduct a proper campaign. The answer lies in his ability to train troops. General McClellan possessed many negative traits; but, he possessed one true strength, he was an excellent trainer of troops. He could take raw recruits and convert them into an effective fighting force within a short amount of time. The reason that his campaigns were not successful was not because of the training of the troops; his campaigns failed because of the lack of leadership skills and ability of the commander. Unfortunately for McClellan he did not have the time to train the troops under his command to his specifications. Instead, on September 4, 1862, he began to prepare to meet the Confederate Army after he heard

\footnotetext{
${ }^{81}$ Ibid., 274.
}

82 Ibid., 273. 
reports that they had crossed the Potomac River. ${ }^{83}$ The next day, President Lincoln authorized General McClellan to take the troops in the Washington fortifications to the field to combat the Confederates that had invaded Maryland. ${ }^{84}$ McClellan had once again been given the opportunity to command the largest army in the Eastern Theater of the Civil War. The historical moment became his once again.

\section{McClellan's Fall from Grace}

Unfortunately for McClellan, his time as a commander would not last. The September 1862 Maryland Campaign started well for the rejuvenated general. When in the morning on September 13, 1862 a member of the Union Army found pieces of paper wrapped around a cigar with the war plans of General Robert E. Lee, the legendary "Lost Orders," the future looked bright for his forces. Unfortunately, McClellan did not go far enough in his effort to end the campaign and the war. With the recovery of the orders from Lee, McClellan knew every move that the Confederates planned to make; therefore, he could position his troops to fight on ground that was of his choosing and, if done correctly, destroy the Confederate army. McClellan positioned the Confederates into the area that he wanted them, but he was unable to fully destroy the Confederate forces. His decision to send in his troops in piecemeal fashion during the September 17, 1862 Battle of Antietam instead of concentrating all of his strength on the Southern lines caused McClellan's troops to not gain a total victory. Even after the battle was over, McClellan's decision to not follow-up on an enemy that was badly bloodied cost him yet another potential victory. But for President Abraham Lincoln, the Battle of Antietam was a large enough victory to issue his preliminary Emancipation Proclamation, which had

\footnotetext{
${ }^{83}$ Ibid., 278.

84 Ibid.
} 
been decided upon by the president since the summer but he had been waiting for a reversal of fortune on the battlefield. ${ }^{85}$ The president also saw the victory at Antietam as a way to pursue and destroy the Confederate army. Unfortunately, McClellan believed that his victory on the battlefield was big enough and that he had forced the Confederates out of Maryland. Instead of chasing the Confederate Army all over Virginia in an attempt to cripple it, McClellan waited for the praise and exultation that he thought he deserved. ${ }^{86}$ President Lincoln urged McClellan to move across the Potomac River into Virginia and place his army between Washington and the forces of Robert E. Lee. Again, McClellan refused to budge, citing logistical concerns and that he did not have the horses need to keep up with the Confederates. ${ }^{87}$ Finally, on November 7,1862 , the president had enough of McClellan not moving and, for the last time, removed him from command; General John Hooker replaced him. ${ }^{88}$

It is something of a surprise that General George McClellan even had a moderately successful military career during the Civil War. The historical moment that existed at the beginning of the Civil War allowed for a man such as McClellan to move up the ranks. He rose from the rank of Captain that he held at the end of his career when he resigned his commission to leader of the Union forces within the first few months of the Civil War in 1861. His rapid rise to generalship can be attributed to his prior experience in the Army; the amount of losses through various forms of attrition that had happened before the war; and that other officers who would show themselves to be more capable were not yet in their prime. General McClellan stayed in the position that he was

\footnotetext{
${ }^{85}$ Waugh, Lincoln and McClellan, 163.

${ }^{86}$ Ibid., 164.

${ }^{87}$ Ibid., $170-174$.

${ }^{88}$ Ibid., 181.
} 
given because no one else existed to fill his position. Generals such as Grant and Sherman were in the Western Theater; Grant made a name for himself in the Illinois Volunteers and Sherman stayed as far away from command as possible. President Lincoln gave McClellan some leeway due to the timing in which he became the Commander of the Army of the Potomac and the General-in-Chief of the Union forces because the president knew that he was working with raw recruits. But, McClellan turned against the president and wore away on the president's patience. By January 1862 he lost his greatest supporter in Edwin Stanton, the Secretary of War, over his conduct and unwillingness to move his troops. The president stripped McClellan of his Generalin-Chief position in April 1862, citing his need to focus on his battlefield troops. After the disastrous 1862 Peninsula Campaign, McClellan lost his troops to General John Pope for the Northern Virginia Campaign that culminated in the disastrous Second Battle of Bull Run. After Second Bull Run, Lincoln appointed McClellan as the commander of the Washington defenses and was allowed to take the field with his army when the Confederates moved into Maryland. After the Battle of Antietam, the culminating engagement of the Maryland Campaign, the president pressed McClellan to destroy the weakened Confederate military. After many refusals to implement the plans that the president presented, Lincoln relieved General McClellan of duty and sent him to New York to await further instructions. General George McClellan rose with the rapidity that few have ever seen in the United States military and fell from his lofty position at almost the same speed. The historical moments that surrounded the Civil War career of George McClellan constitute one of the main reasons for the rapid pace of his rise and fall. However, the historical moment was not the only reason for his rise and fall. 
McClellan's dual reality and his arrogance towards his superiors and subordinates also played a major role. 


\section{CHAPTER IV}

\section{MCCLELLAN AND DUAL REALITY}

General George McClellan's rise and fall can be attributed to many factors: his arrogance towards members of his own command and those in command of him, the historical moment of his rise and fall during the Civil War, and his possible personality disorder. Civil War scholar T. Harry Williams described McClellan as living in a state of duality that caused him to believe that what happened in his mind and what happened in reality were on two planes of existence. ${ }^{89}$ Through the examination of personal and professional correspondence, this chapter provides examples of that dual reality that Williams believed caused McClellan's rise and fall during the Civil War. It analyzes McClellan's hyper-inflation of enemy troops and his deflation of the number of troops in his command before, during, and immediately after the Peninsula and Maryland campaigns in the summer and fall of 1862 . This chapter also examines the relationship between Allan Pinkerton, the celebrated private investigator and General George McClellan. These two men came up with most of the estimates of the enemy numbers that McClellan used throughout his time in command. McClellan seized upon Pinkerton's estimates and expanded on them, a pattern that allowed McClellan to distort the picture of the battlefield on multiple occasions to his superiors.

${ }^{89}$ Williams, McClellan, Sherman, and Grant. 


\section{Early Distortions of Troop Strength}

General McClellan's forays into the fantasy world in which he lived began after he had joined the Union cause during the Civil War. During the conquest of western Virginia, McClellan doubted his troop strength believing that he faced a much larger force of Confederates than existed. On July 12,1861, McClellan sent a telegram to Colonel E. D. Townsend that described how his troops had overrun a position held by 10,000 Confederate troops with minimal losses to the Union side. ${ }^{90}$ Unfortunately, McClellan counted in the number of entrenched men the number of provisions in the Confederate camps. He did not understand that the number of provisions also included some provisions meant for a reinforcement force that never made it to the battlefront. The true total of men that McClellan faced on that day was roughly 5,300 men. Although this example can be seen as a simple error in arithmetic, this episode suggests that McClellan inflated the numbers of the enemy to make his point. The decision to inflate the total numbers of Confederates continued throughout the remainder of his time in command during the Civil War.

When General McClellan entered Washington as the self-professed savior of the Union cause, his pre-disposition to inflating troop numbers came with him. Within a short amount of time McClellan expressed his worry about the number of Confederate troops in the area of Washington. In an August 8, 1861 letter to General Winfield Scott, McClellan explained that his spies told him that at least 100,000 troops existed within

\footnotetext{
${ }^{90}$ McClellan to E. D. Townsend, Beverly, VA, July 12, 1861, in The Civil War Papers of George B. McClellan: Selected Correspondence 1860-1865, ed. Stephen W. Sears (New York: Da Capo Press, 1989), 51-52.
} 
striking distance of Washington. ${ }^{91}$ McClellan explained that a plan to combine most of the forces of the Eastern Theater would alleviate the pressure. McClellan planned to combine the forces of western Virginia, northeast Virginia, Washington, the Shenandoah Valley, Pennsylvania, and Fort Monroe under one commander, preferably himself. ${ }^{92} \mathrm{He}$ explained in the letter that the only reason to call on this number of troops would be to make sure that the capital was secure; interestingly, he used the opposite argument when he took command of the army. Whether McClellan knew that he did not face a force as large as had been stated and that he was using the numbers as justification to anoint himself as the new commander of a much larger force is unknown. Scholars point to this use of numbers as a justification for his anointment to the command of what would become the Army of the Potomac while more cynical scholars see this hyperinflation of numbers as the first in a vast pattern of inflated numbers that marked McClellan's career. On August 18,1861, in a letter to his wife, McClellan commented that the enemy had three to four times his present force and that President Lincoln and General Scott could not see the danger, but he asserted that if the president gave him two weeks to prepare that he would defeat the Confederate forces that surrounded the capital. ${ }^{93}$ This letter is another example of McClellan inflating the numbers with a side note that if he was given enough time by the administration he would defeat the enemy. This process of thinking became the classic McClellan technique: hyper inflate the numbers of the enemy and then

${ }^{91}$ McClellan to Winfield Scott, Washington, August, 8, 1861, in The Civil War Papers of George B. McClellan: Selected Correspondence 1860-1865, ed. Stephen W. Sears (New York: Da Capo Press, 1989), 79-80.

${ }^{92}$ Ibid., 79.

${ }^{93}$ McClellan to Mary Ellen McClellan, Washington, August 18, 1861, in The Civil War Papers of George B. McClellan: Selected Correspondence 1860-1865, ed. Stephen W. Sears (New York: Da Capo Press, 1989), 85. 
lament about what was needed. By the next day, McClellan exclaimed to his wife in a letter that the Confederates had 150,000 troops at the doorstep of Washington while he himself had only $55,000 .{ }^{94}$ This inflation of the Confederate troops rose as the troop levels in his command stayed the same. McClellan used this technique on several occasions, especially during his two major campaigns, the summer 1862 Peninsula Campaign and the September 1862 Maryland Campaign.

\section{McClellan, Troop Numbers and Peninsula and Maryland Campaigns}

McClellan not only hyper-inflated the number of troops that the Confederacy had, he also lowered the number of troops that he had at his disposal. For instance, on December 1, 1861 McClellan claimed that he had 169,452 men present for duty throughout the whole of the Eastern Theater. However, 5,000 of these men were unarmed or unequipped; 27,600 were men off on extra-duty assignments; and 60,000 manned the garrisons throughout the East; in effect McClellan concluded that he had 76,852 soldiers to battle the Confederacy. ${ }^{95}$ The number of men unarmed and unequipped is reasonable as many armies at the time did not have the supply chains to equip every member of their army. However, the other numbers are an inflation of how many men were in each of the roles. The number of men in extra-duty roles is high due to the fact that no army would put fifteen percent of their effective manpower into extraduty roles. Also, the number for those in garrison duties is extremely high given the fact that McClellan placed over thirty-five percent of his manpower in garrison. In reality, the number of effective troops should be closer to 100,000 men.

\footnotetext{
${ }^{94}$ McClellan to Mary Ellen McClellan, Washington, August 19, 1861, in The Civil War Papers of George B. McClellan: Selected Correspondence 1860-1865, ed. Stephen W. Sears (New York: Da Capo Press, 1989), 87.

${ }^{95}$ McClellan, McClellan's Own Story, 79.
} 
Whether McClellan believed that he only had 76.852 effective troops in his command is a point of conjecture; what is known is that his command contained many more troops by the time that his summer 1862 Peninsula Campaign began. It is what he did with the larger number of troops and hyper-inflation of enemy troop totals that signaled McClellan's effectiveness, or in this case, ineffectiveness on the battlefield. McClellan continued to inflate the number of enemy troops during the early stages of the Peninsula Campaign. A telling example of this pattern is the siege of Yorktown. In an April 7, 1862 letter to Secretary of War Edwin Stanton, McClellan concluded that the Confederates had in excess of 100,000 entrenched troops at Yorktown under the command of Major General John B. Magruder. On the other hand, he had 85,000 in his force before eliminating the numbers that would be needed for guards, scouts, and other forms of extra duty ${ }^{96}$ In actuality, the number of Confederate troops, according to historian David Eicher, was closer to 13,000 in the first few days of April. ${ }^{97}$

McClellan's numbers came from reconnaissance reports that he received stating that 40,000 troops had entrenched in Yorktown with an additional 60,000 troops en-route dispatched by General Joseph E. Johnston. Interestingly, McClellan stated in his 1863 report that he concluded during the winter of 1861-62 that General Magruder had a force of 15,000 to 20,000 men in Yorktown..$^{98}$ How McClellan made the analytic leap from

\footnotetext{
${ }^{96}$ McClellan to Edwin Stanton, Yorktown, VA, April 7, 1862, in The War of the Rebellion: A Compilation of the Official Records of the Union and Confederate Armies. Series I, Volume XI, Part I: Reports, comp. and ed. Bvt. Lt. Col. Robert N. Scott (1884, repr., Gettysburg, PA: National Historical Society, 1971), 11-12.

${ }^{97}$ David J. Eicher, Longest Night: A Military History of the Civil War (New York: Simon \& Schuster, 2001), 215.

${ }_{98}$ McClellan to Henry Halleck, Report, New York, August 3, 1863, in 7 The War of the Rebellion: A Compilation of the Official Records of the Union and Confederate Armies.
} 
$15,000-20,000$ men to 100,000 plus is a typical example of his hyper-inflation of the Confederate numbers. McClellan went from his initial numbers, which were close to accurate, to a number five times the actual amount.

This extreme inflation of numbers hampered the effectiveness of the entire campaign. General McClellan sent his forces to probe the defenses of Magruder's line in an effort to find a weak spot to exploit. An amateur actor, Magruder used McClellan's tentative probing as an opportunity to move portions of his army around to appear larger than what it was. The tactic worked; instead of assaulting the defensive works of Magruder, McClellan decided to dig in for a siege. During the time that McClellan's forces dug in, Magruder received reinforcements so that by the middle of April he had 35,000 troops present for duty. According to Civil War historian Stephen Sears, McClellan's forces numbered 121,300 soldiers present for duty at that time. ${ }^{99}$

McClellan worried that the number of troops that he had on hand were not enough for the future fight. He complained to Stanton and President Abraham Lincoln that his numbers did not match up favorably with those of the Confederates. The President decided to make his own calculations of the troop numbers that McClellan had in his command. In an April 9, 1862 letter to McClellan, the President explained that some discrepancy existed between the numbers that McClellan had and the numbers that the President calculated. According to the President McClellan had 108,000 troops available,

Series I, Volume XI, Part I: Reports, comp. and ed. Bvt. Lt. Col. Robert N. Scott (1884, repr., Gettysburg, PA: National Historical Society, 1971), 7.

${ }^{99}$ Stephen W. Sears, To the Gates of Richmond: The Peninsula Campaign (New York: Ticknor and Fields, 1992), 24. 
a far greater number than the 85,000 that General McClellan espoused to have. ${ }^{100}$ President Lincoln encouraged McClellan to act against the Confederacy. The President believed that the more time McClellan wasted the easier it would be for the Confederacy to better their defensive works and bring in reinforcements.

President Lincoln feared the campaign might turn into another Manassas due to the inaction of the Union Army. ${ }^{101}$ In McClellan's report, the general did not dispute the claims of Lincoln about the number of soldiers he had on hand. Instead, he focused on the defensive works of the Confederate Army and how if the President had come to look at them himself, he would have seen that it was foolhardy to attack the works. ${ }^{102}$ The exchange of ideas between the President and McClellan constitutes an example of the strategy that McClellan employed when faced with a reality that did not fit into his world views. Instead of a discussion about the number of troops under his command, he discussed the strength of the defensive positions in an effort to divert the attention away from the question that was set before him -- the gap of 23,000 men between President Lincoln's calculations and his own.

On May 4, 1862, after almost a month, the siege on Yorktown ended. When the Union Army awoke on the morning of the fourth pickets noticed that the Confederates had retreated from their positions during the night. In a May 4, 1862 telegram to General

${ }^{100}$ Abraham Lincoln to George B. McClellan, Washington, April 9, 1862, The War of the Rebellion: A Compilation of the Official Records of the Union and Confederate Armies. Series I, Volume XI, Part I: Reports, comp. and ed. Bvt. Lt. Col. Robert N. Scott (1884, repr., Gettysburg, PA: National Historical Society, 1971), 15.

${ }_{10}$ Lincoln to McClellan, 15.

${ }^{102}$ McClellan to Henry Halleck, Report, August 3, 1863, The War of the Rebellion: $A$ Compilation of the Official Records of the Union and Confederate Armies. Series I, Volume XI, Part I: Reports, comp. and ed. Bvt. Lt. Col. Robert N. Scott (1884, repr., Gettysburg, PA: National Historical Society, 1971), 16. 
Scott, McClellan explained that through deserter reports captured during the day that the Confederate forces numbered 100,000 to 120,000 troops at Yorktown and had a large force of light artillery. ${ }^{103}$ As the Confederates retreated back to Richmond, McClellan, caught off guard by the Confederate's withdrawal during the night, sent forces in pursuit of the retreating army. On May 5, 1862, in Williamsburg, the first major clash of the Peninsula Campaign commenced. In total approximately 41,000 Union and 32,000 Confederate soldiers took part in the action. The end result was a draw, with the action allowing the Confederacy to continue their withdrawal towards their capital of Richmond. McClellan called the battle a brilliant victory in a pair of May 6, 1862 letters to Mary Ellen McClellan, adding that he would have captured 20,000 prisoners if he had gotten to the battle five hours earlier. ${ }^{104}$ In addition, McClellan recounted that the Confederates took a large number of casualties. If this claim was the case, then hypothetically McClellan would have wiped out a considerable number of the Confederate Army.

The Confederate Army retreated back to their capital in an effort to get behind the defensive works that dotted the landscape into the city. McClellan followed behind; but, as he entered the area around Richmond, he made the tactical decision to set up another siege operation. McClellan worried about the number of troops that the Confederacy had in and around the city of Richmond and he felt that the numbers of troops at his disposal was inadequate. In a May 8, 1862 telegram to Edwin Stanton, McClellan asked the

${ }^{103}$ McClellan to Winfield Scott, telegram, Yorktown, VA, May 4, 1862, in The Civil War Papers of George B. McClellan: Selected Correspondence 1860-1865, ed. Stephen W. Sears (New York: Da Capo Press, 1989), 254. ${ }^{104}$ McClellan to Mary Ellen McClellan, Williamsburg, VA, May 6, 1862, in The Civil War Papers of George B. McClellan: Selected Correspondence 1860-1865, ed. Stephen W. Sears (New York: Da Capo Press, 1989), 256-258. 
Secretary of War for all available men in eastern Virginia to assist him in his taking of Richmond. ${ }^{105}$ On May 10, 1862, McClellan sent another telegram to Stanton again asking for all disposable men in eastern Virginia to be sent to him; he claimed that the taking of Richmond may signal the end of the war, but that he faced a force that was over two times the size of his own forces. ${ }^{106}$ In reality, McClellan had approximately 105,000 men while the Confederates had approximately 60,000 . With the Union Army at the door to Richmond, General Johnston prepared to attack the Union lines to relieve the pressure building on the city. ${ }^{107}$

McClellan split the Union Army into two forces upon their approach to Richmond, three corps on the north side of the Chickahominy River and two corps on the south side of the river. General Johnston instituted a plan to attack the two Union corps on the south side of the river with two-thirds of his forces while the other third distracted the Union corps that where still on the northern shore of the river. Unfortunately, Johnson's plan proved flawed. The Confederate assault began on May 31, 1862 and ended on June 1, 1862 with the Confederate forces retreating back to Richmond. The Union offensive against Richmond stopped. The casualty totals for both sides were similar: the Union suffered 5,031 casualties while the Confederates suffered 6,134. ${ }^{108}$ The ferocity of the fighting unnerved McClellan and he moved four of the five corps south of the Chickahominy River. In a June 2, 1862 letter to his wife, he confided to her

${ }^{105}$ McClellan to Edwin Stanton, telegram, Williamsburg, VA, May 8, 1862, in The Civil War Papers of George B. McClellan: Selected Correspondence 1860-1865, ed. Stephen W. Sears (New York: Da Capo Press, 1989), 259.

${ }^{106}$ McClellan to Edwin Stanton, telegram, Williamsburg, VA, May 10, 1862, in The Civil War Papers of George B. McClellan: Selected Correspondence 1860-1865, ed. Stephen W. Sears (New York: Da Capo Press, 1989), 260-261.

${ }^{107}$ Eicher, The Longest Night, 273.

${ }^{108}$ Sears, To the Gates of Richmond, 147. Eicher, The Longest Night, 280. 
that the number of soldiers who died at Seven Pines horrified him and that victory with that much cost attached to it was not worth it. ${ }^{109}$ McClellan kept his troops on the outskirts of Richmond and began the process of digging in. The Union Army sat idle for three weeks waiting for the roads to dry up after an unseasonably wet spring and early summer. While the Union troops sat in their entrenchments further Confederate reinforcements moved to Richmond giving General Robert E. Lee, the new commander of the Army of Northern Virginia, a total of 90,500 troops approximately the same number as McClellan's 90,000. ${ }^{110}$ Lee made the decision to drive the Union Army from the outskirts of Richmond and destroy the army in the process. A series of battles ensued known as the Seven Days' battles.

The first of the engagements took place on June 25, 1862 at Oak Grove when McClellan asked the commander of the Third Corps, Brigadier General Samuel P. Heinzelman to remove the pickets of Confederates in his front. The corps attempted to take the pickets multiple times and was successful in the early evening of June 25 but the delay meant that the Union troops could not take chase after the retreating Confederate soldiers. The casualties for the day included 516 Union casualties and 316 Confederate casualties. ${ }^{11}$ Lee's strategy for the second day of fighting involved attacks against the right flank of Brigadier General Fitz John Porter's Fifth Brigade and cutting the communications between McClellan and his headquarters at White House landing which would, in theory, end McClellan's campaign. The movement made against the Union

${ }^{109}$ McClellan to Mary Ellen McClellan, New Bridge, VA, June 2, 1862, in The Civil War Papers of George B. McClellan: Selected Correspondence 1860-1865, ed. Stephen W. Sears (New York: Da Capo Press, 1989), 287-288.

${ }^{110}$ Eicher, The Longest Night, 282.

${ }^{111}$ Ibid., 283. 
Army became the second battle of the Seven Days' battles, Mechanicsville. On June 26 the Confederates attacked General Porter's lines hoping that he would leave his entrenchments and retreat once he found that his corps faced a superior force. Instead, Porter stayed in his entrenchments and fought back against the onrushing Confederate troops while also slowly retreating to Ellison's Mill. At the end of the engagement the Union casualties amounted to 361 and the Confederates tallied 1,484; a clear, if nominal victory for Porter's corps. ${ }^{112}$ On June 27 the Confederates resumed their attack on the Union forces in the vicinity of Gaines's Mill and forced Porter to move his corps south across the Chickahominy River and relieve the pressure that Porter had been applying on Richmond. Although the Confederate Army came to the battle with approximately 20,000 more troops than the Union, 57,018 to 34,214 , the casualty totals for the day were similar: 6,837 for the Union and 8,751 for the Confederates. ${ }^{113}$

After the fighting at Gaines's Mill, McClellan ordered the whole of the Union Army to retreat to a base on the James River. Although McClellan held the numbers advantage and Major General John Pope had been selected by President Lincoln as the commander of the Army of Virginia as a reinforcement for McClellan, McClellan decided that instead of turning on Lee he would vacate the campaign. McClellan gave away the initiative to his Confederate counterparts. Instead, McClellan sent a telegram to Edwin Stanton in which he stated "If I save this Army now I tell you plainly that I owe no thanks to you or any other persons in Washington -- you have done your best to

112 Ibid., 285.
113 Ibid., 288. 
sacrifice this Army." 114 The final sentence so offended the head of the War Department's telegraph office, Edward S. Sanford, that he omitted the last sentence before giving it to Stanton. Intermittent fighting took place at Garnett's Farm on June 28 and 29 which led to a small number of casualties as opposed to the other battles during the Seven Days': 368 casualties for the Union and 461 for the Confederacy. ${ }^{115}$ Another contest began on June 29 which saw fighting in the area of Savage's Station as the Confederate Army again tried to push the Union Army further from Richmond and in the process destroy them. The fighting continued throughout the day until a thunderstorm and the approach of darkness put an end to the fighting. For the day the Federals lost 1,590 while the Confederates lost 629; the Union also left behind approximately 2,500 wounded soldiers in a field hospital along with a large cache of supplies. ${ }^{116}$ On June 30,1862 , the area around Malvern Hill saw the final day's action. During the battle at Frayser's Farm, Lee directed the divisions of Generals A. P. Hill and James Longstreet to attack the Federal forces during the late afternoon. The battle continued until darkness put an end to the proceedings. Although the battle lasted a little over four hours, the fighting was intense, leaving 3,797 casualties on the Union side and 3,683 casualties for the Confederates. The Confederates failed to destroy the Union line and the Federal line retreated into position on Malvern Hill. With the Union on the high ground, it placed multiple cannon in good positions on the hill that was treeless. Lee attacked on July 1 leading a frontal assault into the cannons of the Union. Lee learned that he needed artillery to soften up the

\footnotetext{
${ }^{114}$ McClellan to Edwin M. Stanton, telegram, Savage Station, VA, June 28, 1862, in The Civil War Papers of George B. McClellan: Selected Correspondence 1860-1865, ed. Stephen W. Sears (New York: Da Capo Press, 1989), 323.

${ }^{115}$ Eicher, The Longest Night, 289.

116 Ibid., 291.
} 
positions before making a frontal assault on an entrenched enemy. Lee sent multiple charges up Malvern Hill and the Union forces repulsed each assault. When the battle came to a close the Union had suffered 3,214 casualties while the Confederates suffered 5,355. ${ }^{117}$ The following day the Union Army withdrew from Malvern Hill and linked up with their commander, McClellan, at Harrison's Landing. Realizing that his forces were too tired and bloodied from the previous seven days, Lee moved his troops back to Richmond. Thus ended McClellan's Peninsula Campaign and in short order Lincoln ordered McClellan back to Alexandria while Lincoln ordered the troops under McClellan's command sent to Pope's Army of Virginia in northern Virginia.

General McClellan was not in attendance for any of the Seven Days' battles. Instead, he routinely stayed within five to seven miles of the battlefield. Had McClellan toured the battlefields, he would have seen that he had the superior forces during a majority of the engagements and would have been able to adjust accordingly with that information. Instead, he decided to listen to reports from spies, intelligence officers, deserters, and prisoners to ascertain the correct number of troops. McClellan's reluctance to tour the battlefields where his troops were fighting allowed for him to continue the notion that he faced a vastly superior Confederate force.

McClellan attempted to keep his troops intact and pleaded for a second chance to take Richmond. Even as his troops fought in the battle of Malvern Hill, McClellan asked various members of the administration and the military for reinforcements that would turn the tide of the war. On July 1, McClellan sent a telegram to General Lorenzo Thomas, Adjunct General, asking for 50,000 more men in order to turn back and fight on

${ }^{117}$ Ibid., 296. 
to Richmond. ${ }^{118}$ The numbers requested by McClellan would continue to grow. On July 3, $1862 \mathrm{McClellan}$ sent a letter to Edwin Stanton asking for 100,000 men in order to turn back towards Richmond. ${ }^{119}$ McClellan's reasoning was that since he calculated that the Confederate Army had 50,000 men guarding Richmond, 100,000 extra men would be able to take the capital. One wonders first how McClellan calculated the number of Confederate troops at 50,000 when he calculated them at close to 200,000 a short time before. 150,000 Confederate troops had disappeared when McClellan could not use them as a fear tactic against the administration, an interesting dilemma for a general trying to save the Union. Interestingly he asked first for 50,000 men and then for 100,000 in short order. It was unknown if McClellan would have asked for reinforcements in perpetuity or if there was a magic number that he had in his head. McClellan probably would have continued to ask for more and more troops, delaying the campaign until the President stepped in and ordered him to start his campaign.

Following the rebuff by the Lincoln administration to give him the reinforcements that he felt he needed, McClellan changed his story. President Lincoln sent McClellan a letter on July 13,1862 that by president's calculations approximately 160,000 men served in the Army of the Potomac during the Peninsula Campaign and that 45,000 men were a part of the Army, but not geographically located with the main force. If McClellan found

${ }^{118}$ McClellan to Lorenzo Thomas, telegram, Turkey Island, VA, July 1,1862 , in The Civil War Papers of George B. McClellan: Selected Correspondence 1860-1865, ed. Stephen W. Sears (New York: Da Capo Press, 1989), 327.

${ }^{119}$ McClellan to Edwin M. Stanton, Harrison's Bar, VA, July 3, 1862, in The Civil War Papers of George B. McClellan: Selected Correspondence 1860-1865, ed. Stephen W. Sears (New York: Da Capo Press, 1989), 333. 
those 45,000 men then he would have the reinforcements that he wanted. ${ }^{120}$ McClellan replied in a July 14 telegram that there were 144,407 men attached to the Army of the Potomac and that 34,472 were absent from duty by authority and that 3,778 were absent without authority, which left 88,665 personnel present for duty. ${ }^{121}$ McClellan understood that some of the absent men were fit for duty and explained to the President that he had been in contact with the War Department in an effort to stop those that were healthy from leaving the battlefield. This letter was cordial and addressed the concerns that President Lincoln had towards the numbers in the Army of the Potomac. Unfortunately, McClellan inflated the numbers of his enemies and suppressed his own numbers in a letter to his wife on July 15. In this letter, McClellan lashed out against the forces in Washington who wanted him to attack Richmond with the force that he had. McClellan exclaimed that he had only 70,000 to 75,000 men ready for duty while the enemy in Richmond had 150,000 to 170,000 men already entrenched. ${ }^{122}$ In a wonderful turn of events, the Confederacy moved 100,000 to 120,000 men into the capital in twelve days while McClellan's own force was dwindling! His changing of the numbers from one day to the next for both the Confederate totals and his own show that he does not live in the same reality as the rest of the world. Tens of thousands of men on both sides cannot just disappear and reappear at the whim of one man.

${ }^{120}$ Abraham Lincoln to George B. McClellan, Washington, July 13, 1862, in The Collected Works of Abraham Lincoln Volume 5, ed. Roy P. Basler (Piscataway, NJ: Rutgers University Press, 1953), 322.

${ }^{121}$ McClellan to Abraham Lincoln, Berkeley, VA, July 14, 1862, in The Civil War Papers of George B. McClellan: Selected Correspondence 1860-1865, ed. Stephen W. Sears (New York: Da Capo Press, 1989), 357.

${ }^{122}$ McClellan to Mary Ellen McClellan, Berkeley, VA, July 15, 1862, in The Civil War Papers of George B. McClellan: Selected Correspondence 1860-1865, ed. Stephen W. Sears (New York: Da Capo Press, 1989), 358. 
On August 24, 1862 Lincoln relieved McClellan of his troops and McClellan sat in Alexandria as a general without an army to command. After the disastrous Second Battle of Bull Run which took place from August 28-30 1862, Lincoln put McClellan in charge of the defenses of Washington. At that time the Confederate Army with approximately 55,000 troops moved north into Maryland to relieve the pressure on Virginia. ${ }^{123}$ Lincoln sent McClellan from Washington with 84,000 troops to stop the advance of the Confederate Army. ${ }^{124}$ Within four days of moving into Maryland, McClellan had inflated the number of troops that he faced. In a September 9, 1862 letter to his wife, McClellan asserted that 110,000 troops had crossed the Potomac River and were now in Maryland, a number double the size of the actual size. ${ }^{125}$ By September 11, 1862 the number had grown to 120,000 when McClellan sent an urgent letter to Major General Henry Halleck, the new General-in-Chief. ${ }^{126}$ These increasingly fantastic numbers ended when the Union Army found the infamous "Lost Order" that detailed the plans of the Confederate forces. ${ }^{127}$ True to his form, McClellan did not take full advantage of the intelligence coup. Instead, after Antietam on September 17, 1862,

${ }^{123}$ Eicher, The Longest Night, 337.

${ }^{124}$ Ibid., 338.

${ }^{125}$ McClellan to Mary Ellen McClellan, Rockville, MD, September 9, 1862, in The Civil War Papers of George B. McClellan: Selected Correspondence 1860-1865, ed. Stephen W. Sears (New York: Da Capo Press, 1989), 442.

${ }^{126}$ McClellan to Henry Halleck, telegram, Rockville, MD, September 11, 1862, in The Civil War Papers of George B. McClellan: Selected Correspondence 1860-1865, ed. Stephen W. Sears (New York: Da Capo Press, 1989), 447.

${ }^{127}$ Sears, The Young Napoleon, 280. On September 13, 1862 Corporal Barton Mitchell discovered an envelope that held three cigars wrapped in official paper with the heading "Special Orders Number 191" and signed by General Robert E. Lee. Corporal Mitchell took the papers to his company commander who in turn sent it on to Twelfth Corps Headquarters. The commander of the Twelfth then sent the orders to McClellan without delay. The orders outlined the plans to attack Harper's Ferry and which Confederate forces were to take part in the attack. Armed with this information McClellan held a tremendous advantage. 
McClellan chose not to chase after the retreating Confederates for fear that their numbers were still too large and his soldiers too tired. Unmolested, McClellan allowed for the Confederate Army to slip back across the Potomac River. The decision to not chase after the retreating Confederates while McClellan had numerical superiority caused his dismissal on November 10, 1862.

\section{Pinkerton and McClellan}

Scholars have pointed to faulty information provided by Allan Pinkerton and his agents as a reason why McClellan believed that he faced a force larger than his own. But upon closer scrutiny, it becomes clear that McClellan deceived Pinkerton into setting such high numbers for the troop levels associated with the Confederacy. In his June 1988 article for Civil War History entitled "Pinkerton and McClellan: Who Deceived Whom?" historian Edwin Fishel explored the possibility that McClellan was the reason for the hyper-inflated numbers and not Pinkerton. Fishel concluded that Pinkerton was not the bumbler that other scholars had argued and that McClellan was also not deceived by the numbers given to him by the agent. ${ }^{128}$ Fishel contended that McClellan added troops to Pinkerton's totals if not enough of the enemy existed for his purposes.

McClellan also made gross inflations of enemy troop strength even before Pinkerton acted as a scout for him. While McClellan made the first troop strength estimate of 100,000 after the First Battle of Bull Run, in which the actual total number of Confederate troops was closer to 30,000 , Pinkerton was still setting up his operation in Washington. ${ }^{129}$ Although McClellan claimed that his estimates came from reliable

\footnotetext{
${ }^{128}$ Edwin C. Fishel, "Pinkerton and McClellan: Who Deceived Whom?" Civil War History 34 (June 1988): 115.

${ }^{129}$ Ibid., 116.
} 
sources such as telegrams and spies, the general used rumors and mere guesswork. ${ }^{130}$

During his time with McClellan, Pinkerton only provided six reports to McClellan even though McClellan issued many more warnings about the size of the enemy to his superiors. McClellan derided the estimates that came from his subordinates because he felt that they were inferior to him; therefore, McClellan may have invented the troop counts that showed up in the warnings sent to the Lincoln administration. ${ }^{131}$ On October 4,1861 , Pinkerton issued his first estimate on the troop strength of General Joseph Johnston's army. Pinkerton estimated the enemy troops at 98,400 men, a figure that was forty percent less than McClellan had indicated, but still seventy percent above the actual number of troops available fot the battlefield. ${ }^{132}$ Although Pinkerton's estimations continued to be high, McClellan's estimates grew even higher than Pinkerton's. In effect, if Pinkerton came up with the larger number than McClellan, the general would use that number, but if McClellan obtained a higher number from another source than he would use that one. The decision to inflate the enemy troop numbers by McClellan led to Pinkerton having to inflate his numbers so that McClellan would use them. It became a higher numbers game until McClellan was happy with the result; therefore the numbers failed to reflect reality. Pinkerton worked with McClellan from the time that McClellan came to Washington through the end of his command. Fishel commented that Pinkerton's overarching character trait was that of personal loyalty bordering on ubiquitous flattery towards McClellan. ${ }^{133}$ That personal loyalty led Pinkerton to pump up his own estimates so that McClellan would find them more palatable. For McClellan,

\footnotetext{
${ }^{130}$ Ibid., 117.

${ }^{131}$ Ibid., 118.

132 Ibid.

${ }^{133}$ Ibid., 140.
} 
Pinkerton constituted an indispensable tool in the inflation of enemy troop numbers.

McClellan's dual reality played a major role in his rise and fall. His decisions to hyper-inflate the troop totals of the enemy and repress the totals of his own troops demonstrated that he lived in two separate parallel worlds: one of his own making and the other world of actual reality. Living in and with both of these realities McClellan justified the reasoning behind not attempting to fight the enemy when they were in front of him. Although McClellan has to take the blame for these mistakes, some scholars believe that the true force behind the hyper-inflation of enemy troops was Allan Pinkerton. This argument has been overturned most notably by Edwin Fishel in his article about the relationship between McClellan and Pinkerton. Throughout his career as a Civil War commander, George McClellan lived in two different realities according to T. Harry Williams, and these two realities led to the downfall of America's young Napoleon. 


\section{CHAPTER V}

\section{THE ARROGANCE OF MCCLELLAN}

General George McClellan's personality played a pivotal role in his rise and fall. Beginning in 1842 his earliest days as a cadet at the United States Military Academy through his service in the 1846-1848 Mexican War, General McClellan's arrogant nature became evident. However, his arrogance crescendoed during the Civil War. From the outbreak of hostilities in April 1861 until his dismissal from active military service by President Abraham Lincoln on November 10, 1862, McClellan believed that the army he commanded should be the focus of all military operations for the Union Army. Although General McClellan had resigned from the army in 1856 at the rank of captain, he believed that his expertise garnered a higher rank in the Union Army when the hostilities began. Although he was arrogant, he helped the Union during the Civil War. He created a force that he felt was unstoppable on the battlefield and he instituted a training regimen to turn raw recruits into disciplined soldiers. He also understood that a well-supplied soldier fought better than one that was ill-equipped. These values proved to be decisive in the Civil War. It was not that his arrogance was his fatal flaw, as all good commanders have a certain amount of arrogance; it was that he worried more about his personal ambition than winning the war. Although George McClellan couched his arrogant decisions within the framework that he was only doing what God sent him to do, his religious fervor was an excellent excuse to pursue personal goals instead of the goals of the 
country. Then, when General McClellan ascended to the highest ranks that a soldier could attain, McClellan began to have higher aspirations, which, combined with his slowness in taking advantage of the numerous advantages laid before him, caused his star to fall as quickly as it had risen. This chapter relies heavily on the personal correspondence between McClellan and various people in his life. The most telling letters are to his wife, Mary Ellen McClellan, as he expresses his true inner-self, one that cannot be shown to the public or those who worked with him. This chapter examines that rise and fall through the lens of General McClellan's arrogance from commander of the Ohio militia to Commander-in-Chief and finally as the commander of the Army of the Potomac.

McClellan's arrogance stemmed from his probable personality disorder that affected him through his life. According to Civil War historian Joseph Glatthaar, McClellan exhibited a classic personality disorder; a personality disorder that manifested itself into narcissistic tendencies. ${ }^{134}$ Glatthaar relayed multiple stories of McClellan's narcissistic behavior before the Civil War towards his superiors. In one such story, McClellan contended that the professors at West Point showed preference to the student that came ahead of him in the class ranking structure. ${ }^{135}$ In another, while he was on a scouting expedition for Governor Isaac Stevens for possible railroad routes through the Pacific Northwest in 1853, he clashed with Stevens when the Governor disagreed with his judgment. McClellan refused to help with the reconnaissance because Stevens had issued an order to continue looking for a railroad route in direct conflict with McClellan's

${ }^{134}$ Glatthaar, Partners in Command, 238.

135 Ibid., 240. 
assessment of the situation. ${ }^{136}$ McClellan's assertions were that he was right and everyone around him was wrong. Unfortunately for the Union cause at the beginning of the war, this trait became exposed throughout his tenure as commander.

\section{George McClellan and the Western Theater}

George McClellan answered the call to arms for the Union Army with the same fervor that he attacked the rest of his life. During the secessionist crises of late 1860 through early 1861 McClellan worked as the Vice President for the Illinois Central Railroad. When open hostilities broke out between the North and South, George McClellan volunteered to become a part of the Union cause. His first goal was to attain a rank that he believed was commiserate with the skills he learned and experience that he had while in the Army during the Mexican War. He contacted old acquaintances from the Army in an effort to obtain a high ranking position in the Union Army. The governors of Pennsylvania and Ohio offered McClellan two distinct positions, one working with the Pennsylvania volunteers and the other working with the Ohio volunteers. On April 18, 1861, McClellan wrote a letter to Major General Robert Patterson, commander of the Pennsylvania three-month volunteers, and explained that if he was to come to Pennsylvania as the Chief Engineer for the Pennsylvania volunteers, the rank of Brigadier General should be conferred upon him. McClellan argued that he would serve Patterson better as an officer of higher rank than the rank that he held when he left the military. ${ }^{137}$ In spite of these negotations, these efforts did not result in success. McClellan was also in communication with the Governor of Ohio, William Dennison, for

136 Ibid., 241.

${ }^{137}$ McClellan to Major General Robert Patterson, Cincinnati, April 18, 1861, in The Civil War Papers of George B. McClellan: Selected Correspondence 1860-1865, ed. Stephen W. Sears (New York: Da Capo Press, 1989), 5. 
a possible position within the Ohio militia. On April 23, 1861 Governor Dennison conferred upon McClellan the rank of Major General and installed him as Commander of the Ohio troops.

McClellan wasted little time in his new duties as commander of the Ohio militia; on April 23, 1861 General McClellan asked Winfield Scott, the General-in-Chief of the Union Army, for a great number of arms and ammunition to be sent to Cincinnati so that his troops could be properly armed. The request for arms and ammunition was not itself an odd request, but McClellan asked for all arms to he sent to him from both the St. Louis, Missouri and Dearborn, Michigan armories, beyond his scope as commander of the Ohio volunteers. ${ }^{138} \mathrm{McCl}$ llan believed that Cincinnati was the primary focal point for any fighting west of the Alleghany Mountains and this belief became a running theme throughout his various roles in the Civil War. McClellan's ambition to make the Western theater the focal point of the Civil War can be seen in this letter to Winfield Scott. Five days later, in his second letter to Winfield Scott on April 27, 1861 it becomes more evident that General McClellan saw the Western theater as the most important theater in the Civil War. In this letter, McClellan laid out the battle plans that he had worked on in order to destroy the Confederate cause. He laid out two plans in order to destroy the Confederacy. The first was to take a contingent of 80,000 troops from Cincinnati, Ohio through the Kanawa Valley of western Virginia to Richmond. If that plan was not feasible, the other plan was to march with those same 80,000 troops from either Cincinnati or Louisville, Kentucky and strike at the heart of the western Confederacy at

\footnotetext{
${ }^{138}$ McClellan to Lieutenant General Winfield Scott, Columbus, OH, April 23, 1861, in The Civil War Papers of George B. McClellan: Selected Correspondence 1860-1865, ed. Stephen W. Sears (New York: Da Capo Press, 1989), 7.
} 
Nashville. Then if the battle at Nashville went according to plan, he would march the troops on to Montgomery, Alabama in order to break the back of the secessionist cause. $^{139}$ While only the commander of the Ohio militia, McClellan sought to dictate the war plans of the entire Union. His ambitious plan to break the Confederacy highlighted in detail his need to be at the center of the action during the Civil War, and his plans did not take into account any other plan by the Union or the Confederacy than his own. Interestingly this plan also did not take into account the breakdown of men and horses that would occur during the march from Cincinnati to Montgomery, an excuse that he would later use as a reason why the Union Army did not move as quickly as President Lincoln felt it needed to after both the Peninsula and Maryland campaigns.

McClellan's arrogant nature had already begun to wear on General Scott. As commander of Ohio's militia, McClellan had overstepped his authority in submitting plans with himself at the front, when Scott objected to these plans, citing numerous deficiencies within the plan, McClellan, in a letter to Governor Dennison, asked that the Governor not bring up his name in front of General Scott since "General Scott is as you are aware eminently sensitive, and does not at all times take suggestions kindly from military subordinates, especially when they conflict with his own preconceived notions." 140 This episode signaled the beginning of the break between General Scott and General McClellan. McClellan's plans were not feasible at the time, but he took the dismissal of his plans by the General as Scott being too sensitive and unwilling to look at

${ }^{139}$ McClellan to Lieutenant General Winfield Scott, Columbus, $\mathrm{OH}$, April 27, 1861," in The Civil War Papers of George B. McClellan: Selected Correspondence 1860-1865, ed. Stephen W. Sears (New York: Da Capo Press, 1989), 12.

${ }^{140}$ McClellan to Governor William Dennison, telegram, Cincinnati, May 25, 1861, in The Civil War Papers of George B. McClellan: Selected Correspondence 1860-1865, ed. Stephen W. Sears (New York: Da Capo Press, 1989), 25. 
other plans other than his own. McClellan's ambitious temperament got in the way of him thinking through the problem at hand. Instead, McClellan sought to install a plan where his forces were at the front and where he would collect the glory for crushing the Confederacy. McClellan's ambitions began to change in early May, 1861 as he was named the Commander of the Department of the Ohio as a Major General in the United States Army, a post that gave him command of all troops in Ohio, Indiana, Illinois, and later the western portion Pennsylvania, western Virginia, and Missouri. At that point McClellan commanded a large contingent of troops west of the Appalachian Mountains and it would only be a matter of time before the United States government called on McClellan to use those forces.

\section{McClellan's Rise to General-in-Chief}

Confederate forces occupied the western portion of Virginia, a region that had Unionist leanings and also included a portion of the Baltimore and Ohio railroad, the main railway used by the Union between the eastern theater and the Department of the

Ohio. On May 26, 1861, General McClellan received reports that the Confederate forces had burned the railroad bridges of the Baltimore and Ohio, effectively cutting off the Department of the Ohio from the rest of the Union Army. McClellan took this opportunity to strike at the Confederates in the area particularly the force surrounding the town of Grafton, a key railroad junction. ${ }^{141}$ Before the Union Army's entrance into western Virginia, General McClellan issued a proclamation to the citizens of western Virginia. In this proclamation, McClellan wrote what he believed to be the Union Army's goals in western Virginia:

$\overline{{ }^{141} \text { Sears, The Young Napoleon, } 79 .}$ 
Your homes, your families and your property are safe under our protection. All your rights shall be religiously respected.

Nothwithstanding all that has been said by the traitors to induce you to believe that our advent among you will be signalized by interference with your slaves, understand one thing clearly - not only will we abstain from all such interference but we will on the contrary with an iron hand, crush any attempt at insurrection on their part. ${ }^{142}$

This ambitious proclamation served notice that the Union Army would not interfere with the practice of slavery within western Virginia. Once again, General McClellan had overstepped his authority when issuing this proclamation. He had received no orders to institute a strict policy on protecting slaveholder's possessions, but McClellan took it upon himself to do so. In this statement, McClellan spoke for the entire Union Army and his arrogant nature in writing this proclamation put him at odds with the public policies of the federal government. After the issuance of the proclamation, McClellan began to have misgivings about it. In a May 30, 1861 letter to President Lincoln, General McClellan explained that the proclamation was well received in Kentucky and that he was sorry that he was not able to send the proclamation to the President beforehand, but it was written and sent in great haste. McClellan expressed that the proclamation was in line with how the President and the federal government felt about the slavery question, and if it is not than he is truly sorry since the intimation was made that it was on authority from the President. ${ }^{143}$ This letter constituted the first letter sent directly to the President. Instead of using the correct military channels to speak with the President, McClellan sent

${ }^{142}$ McClellan to the Union Men of Virginia, proclamation, Cincinnati, May 26, 1861, in The Civil War Papers of George B. McClellan: Selected Correspondence 1860-1865, ed. Stephen W. Sears (New York: Da Capo Press, 1989), 26.

${ }_{143}$ McClellan to President Abraham Lincoln, Cincinnati, May 30, 1861, in The Civil War Papers of George B. McClellan: Selected Correspondence 1860-1865, ed. Stephen W. Sears (New York: Da Capo Press, 1989), 28. 
a letter directly to him bypassing the chain of command. McClellan sent an imprudent proclamation to the people of western Virginia and then followed it up with an audacious letter to the Commander-in-Chief. McClellan's arrogance grew. This episode would not be the last time that McClellan overstepped his position; from this point forward he sent letters to the president without them being first sent through the proper channels. As a result, this display of arrogance harmed the relationship between McClellan and his superior, General Winfield Scott.

McClellan's troops found remarkable progress in western Virginia. Unfortunately, McClellan felt that his troops would do much better if they were under the leadership of men with formal military training instead of those appointed to commands for political purposes. In a June 26, 1861 letter to Salmon P. Chase, the Secretary of War, McClellan highlighted the need for more informed commanders, especially those that had formal military training. It was McClellan's belief that the troops under his command were well equipped and need only the handling of a trained officer corps to win on the battlefield. ${ }^{144}$ The confidence that McClellan felt for his troops was a reflection on him. He had trained these men while in Ohio and had the confidence that the training he provided would lead to a substantial victory for the Union in western Virginia. On the other hand, he showed his lack of confidence for those officers that did not have substantial military experience. Within two months, McClellan asked the Secretary of War to send him more experienced officers, preferably those that had been trained at the United States Military Academy at West Point. This lack of confidence in

\footnotetext{
${ }^{144}$ McClellan to Salmon P. Chase, Grafton, VA, June 26, 1861, in The Civil War Papers of General George B. McClellan: Selected Correspondence 1860-1865, ed. Stephen W. Sears (New York: Da Capo Press, 1989), 37.
} 
his subordinate military commanders also grew during the campaign into western Virginia.

The lack of respect and confidence can be explained with an example of the way McClellan treated most of his subordinate commanders. McClellan worried that his subordinate commanders had become preoccupied with the number of Confederate troops in the area and that the commanders lacked the skill and initiative to win a convincing battle in the region. McClellan's worry about the lack of initiative from his commander constituted an interesting conundrum since McClellan would later be charged with the same lack of initiative while on the Peninsula Campaign and after the battle of Antietam. In a July 3,1861 , letter to Brigadier General Thomas A. Morris, McClellan forcefully rebuked the general for asking for reinforcements. In part of the letter he states:

I must have Generals under me that are willing to risk as much as I am, and to be content to risk their lives and reputation with such means as I can give them. Let this be the last of it-give me full details as to the information you obtain-not mere rumors, but facts --and leave it to my judgment to determine what force you need. I wish action now and determination. ${ }^{145}$

McClellan's explanation that he must have generals who were willing to risk as much in their lives and reputation as himself makes sense when considering Morris' request for additional troops as an isolated incident. McClellan tested Morris' masculinity, to have the general understand that he would not be receiving additional troops. The earlier that Morris understood that, the better off he and the soldiers under him would be. But the traits that McClellan rebuked are the same traits that he showed signs of later in his campaigns. But McClellan was not happy with just sending a letter of

${ }^{145}$ McClellan to Thomas A. Morris, Buckhannon, VA, July 3, 1861, The Civil War Papers of General George B. McClellan: Selected Correspondence 1860-1865, ed. Stephen W. Sears (New York: Da Capo Press, 1989), 43. 
rebuke to Morris. In a letter to his wife on that same day, McClellan insulted his subordinate generals: he called Morris “a timid old woman," Brigadier General William Rosecrans "a silly goose," and related that Brigadier General Newton Schleich "knows nothing." ${ }^{146}$ Later, in a telegram to E. D. Thompson dated July 6, 1861, McClellan requested that he be sent officers that understood the nature of war and that if he was not there to personally oversee all preparations and the battle itself then the Union would lose the war. ${ }^{147}$ McClellan's confidence in his officers waned while in western Virginia while his own self-confidence soared. In the same telegram he declared that he was the only commander that was worth anything in his army and that if he did not watch every movement that was made by his subordinates than all was lost. ${ }^{148}$ His thoughts on his subordinate commanders did not change once he became the commander of the Army of the Potomac and the General-in-Chief of the Union forces, if anything the hubris that he felt for his subordinate commanders grew.

Following McClellan's triumphs in western Virginia contrasted to the disastrous battle at First Bull Run on July 21, 1861 under the direction of Brigadier General Irwin McDowell, the federal government called General McClellan to the capital. McClellan's arrogance comes to the fore in a letter written to his wife, Mary Ellen McClellan, on July 26,1861 . In that letter he explained that all members of the federal government deferred to him in all matters, as if he is the absolute power throughout the nation. He closed by

${ }^{146}$ McClellan to Mary Ellen McClellan, Buckhannon, VA, July 3, 1861, in The Civil War Papers of General George B. McClellan: Selected Correspondence 1860-1865, ed. Stephen W. Sears (New York: Da Capo Press, 1989), 44.

${ }^{147}$ McClellan to E. D. Thompson, telegram, Buckhannon, VA, July 6, 1861, The Civil War Papers of General George B. McClellan: Selected Correspondence 1860-1865, ed. Stephen W. Sears (New York: Da Capo Press, 1989), 49.

${ }^{148}$ McClellan to Thompson, 49. 
mentioning that he could easily become dictator of the country if he wanted, but instead he concluded, ". . . but nothing of the kind would please me-therefore I won't be Dictator. Admirable self denial!"149 This letter began a string of letters sent to his wife in which McClellan made note that he could be ruler of the Union if he so chose. Although he made the point to deny such feelings, it is obvious that he had concluded he was deserving of such a position. This arrogant tone taken by McClellan in this letter shows what heights he planned to attain while in the position as commander.

In a later letter to his wife on August 4, 1861, McClellan revealed his true intentions towards the position of General-in-Chief. McClellan explained that General Winfield Scott leaned on McClellan throughout a state dinner at the Presidents home. McClellan related that many people at the dinner contrasted Scott and McClellan by labeling them as the old soldier and his successor. ${ }^{150}$ This letter demonstrated the frankness and arrogance in McClellan's demeanor that he would be the next General-inChief and Winfield Scott is the only person who stood in his way. Soon after this letter to his wife, McClellan turned on General Scott which led to frostiness in their relationship; but McClellan's arrogant nature would not allow the old soldier to go gracefully, instead he had to cement his place as the head of the Union Army. On August $4,1861, \mathrm{McClellan}$ wrote a letter to his wife again lambasting General Scott as "either a

${ }^{149}$ McClellan to Mary Ellen McClellan, Washington DC, July 26, 1861, in The Civil War Papers of George B. McClellan: Selected Correspondence 1860-1865, ed. Stephen W. Sears (New York: Da Capo Press, 1989), 70.

${ }^{150}$ McClellan to Mary Ellen McClellan, Washington DC, August 4, 1861, in The Civil War Papers of George B. McClellan: Selected Correspondence 1860-1865, ed. Stephen W. Sears (New York: Da Capo Press, 1989), 78-79. 
dotard or a traitor!" ${ }^{151}$ McClellan had two complaints about General Scott. First, McClellan argued that General Scott could not see the severity of the situation at hand; and, second, that Scott stood in the way of any successes that McClellan could have on the battlefield. McClellan's stance was clear -- if Scott was not removed and McClellan put in his place, then McClellan would resign from his position and the army. ${ }^{152}$ This position was the first of many instances that McClellan would threaten to tender his resignation if all of his wishes were not fulfilled. Instead of working through the problem with General Scott, McClellan's ambitious leanings saw only one outcome: either he became General-in-Chief or he resigned.

One day later in a letter to Mary Ellen, McClellan signaled what his plans were for Winfield Scott. Again McClellan called Scott a traitor and mentioned that he was the only obstacle in his way to certain victory. He explained that he had penned a letter to the Cabinet and that it would lead to his being called upon as the General-in-Chief of the Union Army. McClellan understood that this letter would cause personal animosity between himself and General Scott, but he could not allow anyone to stand in the way of saving the Union. ${ }^{153}$ Later in this letter, he again mentioned that many people asked him to become President or dictator. He shrugged it off stating, "I will never accept the Presidency -- I will cheerfully take the Dictatorship and agree to lay down my life when

${ }^{151}$ McClellan to Mary Ellen McClellan, Washington DC, August 8, 1861," in The Civil War Papers of George B. McClellan: Selected Correspondence 1860-1865, ed. Stephen W. Sears (New York: Da Capo Press, 1989), 81.

${ }^{152}$ McClellan to McClellan, 81.

${ }^{153}$ McClellan to Mary Ellen McClellan, Washington DC, August 9, 1861, in The Civil War Papers of George B. McClellan: Selected Correspondence 1860-1865, ed. Stephen W. Sears (New York: Da Capo Press, 1989), 81. 
the country is saved."154 President Lincoln showed this letter to General Scott. Scott was understandably upset by the actions taken by McClellan and tendered his resignation on that date. Instead of accepting the resignation, Lincoln showed a second letter that McClellan had written to the president on August 10, 1861 in which he expressed his sincere condolences and that he meant no harm to General Scott. ${ }^{155}$ President Lincoln then requested that General Scott remove his request of resignation which begrudgingly Scott did. This episode would be the first in a long line of internal disputes between Generals Scott and McClellan. Scott understood that McClellan wanted his job as General-in-Chief, but he stayed on as a personal favor to President Lincoln. If General Scott thought that the trouble with General McClellan had ended with the President's intervention, he was wrong.

General McClellan directed his vitriol at General Scott after the affair on August 10, 1861, but he also found a new target, President Abraham Lincoln. In a letter written on August 14, 1861 to his wife, McClellan explained to her that the President was "an idiot" and General Scott was his willing accomplice for not seeing the danger that was near the capital. ${ }^{156}$ In this letter, McClellan explains his ambition to save the country; he wrote:

I have no ambitions in the present affairs-only wish to save my country and find the incapables around me will not permit it! They sit on the verge of the precipice and cannot realize what they see-their reply to

154 McClellan to McClellan, 81.

${ }^{155}$ McClellan to Abraham Lincoln, Washington DC, August 10, 1861, in The Civil War Papers of General George B. McClellan: Selected Correspondence 1860-1865, ed. Stephen W. Sears (New York: Da Capo Press, 1989), 83.

${ }^{156}$ McClellan to Mary Ellen McClellan, Washington DC, August 16, 1861, in The Civil War Papers of George B. McClellan: Selected Correspondence 1860-1865, ed. Stephen W. Sears (New York: Da Capo Press: 1989), 86. 
everything is "Impossible! Impossible!" They think nothing possible which is against their wishes. ${ }^{157}$

McClellan couched his ambitions in the terms that he wanted nothing more than to save the country. He felt as if the others were playing political games and that he was the only one that took the threat to the capital seriously. Therefore, the only way in which to make the capital safe was for the Lincoln administration to give McClellan the position that he felt that he deserved as General-in-Chief of the Union Army.

When McClellan came to Washington to assist in the defense of the capital, his thoughts of his subordinate officers did not change. Instead, in a letter written to his wife on September 6, $1861 \mathrm{McClellan}$ exclaimed that he must ride out to every fortification to make sure that the troops are in the proper position since he cannot trust his officers to do their jobs. ${ }^{158}$ In reality McClellan took this action for a different set of reasons, he wanted to make sure that the troops under his command knew who their commander was and that when the time came they would rally around him. If McClellan felt that his subordinate officers were not doing their jobs he could have asked for their dismissal. His political clout gave him the leverage to make any changes that he deemed necessary. Instead, he kept a number of those officers in their commands and harassed them about their abilities as officers.

The bitter stalemate between General Scott and General McClellan continued for the rest of the summer and into the fall of 1861 . In private letters, McClellan called General Scott numerous names. Finally, in early October, the feud reached a boiling

\footnotetext{
${ }^{157}$ McClellan to McClellan, 86.

${ }^{158}$ McClellan to Mary Ellen McClellan, Washington DC, September 6, 1861, The Civil War Papers of General George B. McClellan: Selected Correspondence 1860-1865, ed. Stephen W. Sears (New York: Da Capo Press, 1989), 95.
} 
point. In early October 1861 General Scott sent some of McClellan's troops to Kentucky in order to institute the beginning stages of his over-arching Anaconda battleplan. ${ }^{159}$ McClellan blocked the moves and explained his intentions in an October 10, 1861 letter to his only confidant, his wife. In the letter he explained that General Scott tried to move some of his troops, but was unsuccessful. McClellan believed that the reason for the move was because General Scott was jealous and will always be jealous of anyone who acquired even a modicum of distinction. ${ }^{160}$ Interestingly, McClellan could not understand why General Scott was behaving this way toward him. His arrogance made it appear that all those that did not see the world in the same way as he did were wrong. McClellan could not see that his arrogance placed his superiors into awkward situations. Finally, on November 1, 1861 McClellan got his wish, and Lincoln named him as the new General-in-Chief of the Union Army when General Scott resigned the position. Although McClellan had attained the position that he had sought for so long, he commented to his wife in a letter that although he had finally attain the position that he had strived for he was not all powerful and that many would try to thwart him. He wrote:

The people think that I am all powerful. Never was there a greater mistake-I am thwarted and deceived by these incapables at every turn . . . I have one great comfort in this-that I did not seek this position, as you well know, and I trust that God will support me and bear me out-he could not have placed me here for nothing ... I feel a sense of relief at

${ }^{159}$ The "Anaconda Plan" was the strategy devised by General Winfield Scott to end the Civil War by cutting off resources to the Confederacy. By placing troops in strategic locations along railroad junctions and the major waterways connected to the South, mainly the Mississippi River, the Gulf of Mexico and the Atlantic Ocean, Scott hoped to choke the Confederacy into submission. After securing the railway junctions and waterways, the Union Army would continue to tighten the chokehold on the Southern States much like an Anaconda suffocates its prey.

${ }^{160}$ McClellan to Mary Ellen McClellan, Washington DC, October 6, 1861, in The Civil War Papers of George B. McClellan: Selected Correspondence 1860-1865, ed. Stephen W. Sears (New York: Da Capo Press, 1989), 106. 
the prospect of having my own way untrammelled, but I cannot discover in my own heart one symptom of gratified vanity or ambition. ${ }^{161}$

McClellan had attained his goal of becoming the General-in-Chief of the Union Army. As commander of both the army of the Potomac and General-in-Chief, McClellan became the most powerful military man in the Union. The question became how he would use this new power to bring an end to the war. Unfortunately, McClellan's arrogance clouded his judgment and led to him being ousted first as General-in-Chief of the Union Army and, then later, as Commander of the Army of the Potomac.

\section{Unabashed Arrogance: The Fall of General George McClellan}

After a winter of non-action that McClellan blamed on everyone but himself, the Army of the Potomac prepared to embark on what was called then and since, the Peninsula Campaign. This campaign pushed the war to the gates of Richmond and, McClellan hoped, it would end the Civil War once and for all in the Union's favor. McClellan's first order of business is to create an army large enough to defeat the Confederate forces that he would encounter on his road to Richmond. On March 16, 1862 he sent a letter to Secretary of War Edwin Stanton outlining his need for additional troops for the upcoming campaign; but instead of asking for troops from different regions, he insisted that the Department of Virginia and the Department of the Potomac be merged into one force, the Department of the Chesapeake. ${ }^{162}$ Of course General McClellan would head this new department and he further asked that the commander of

${ }^{161}$ McClellan to Mary Ellen McClellan, Washington DC, October 31, 1861-November 1, 1861, in The Civil War Papers of George B. McClellan: Selected Correspondence 18601865, ed. Stephen W. Sears (New York: Da Capo Press, 1989), 114.

${ }_{162}$ McClellan to Edwin M. Stanton, Washington DC, March 16, 1862, in The Civil War Papers of George B. McClellan: Selected Correspondence 1860-1865, ed. Stephen W. Sears (New York: Da Capo Press, 1989), 212-213. 
the Department of the Virginia, Major General John E. Wool, be placed in command elsewhere. ${ }^{163}$ Stanton agreed. On March 18, 1862 Wool, who was one of McClellan's superiors in the Mexican War, renounced his status as a military superior of McClellan. Later, on June 1, 1862, the Army transferred Wool to the Middle Department. General McClellan's plans had once again paid off for him. He commanded a vast army with numerous resources at his disposal. Even with the number of men at his disposal, the Peninsula Campaign turned out not to be the shining moment that McClellan envisioned. For numerous reasons his plan did not work; but, McClellan did not put the blame on to himself. He blamed the weather, the shortage of troops that he thought that he had, and the Lincoln administrated government. McClellan felt the need to place himself as the epitome of a commander and soldier, that all of the problems that plagued the campaign were completely out of his control.

Although his army was in turmoil after the 1862 Peninsula Campaign, McClellan was still found time to write to the President and to provide him his views on how the country should precede both in military and civil matters. McClellan outlined the steps that should be taken by the federal government in ending the rebellion. In a July 7,1862 letter McClellan wrote:

It should not be a War looking to the subjugation of the people of any state, in any event. It should not be, at all, a War upon population; but against armed forces and political organizations. Neither confiscation of property, political executions of persons, territorial organization of states or forcible abolition of slavery should be contemplated for a moment. ...Military power should not be allowed to interfere with the relations of servitude either by supporting or

${ }^{163}$ McClellan to Stanton, 212-213. 
impairing the authority of the master; except repressing disorder as in other cases. ${ }^{164}$

Even though McClellan had just concluded a campaign that ended with his embarrassing withdrawal from the Richmond suburbs, he still had the arrogance to discuss with the President what needed to be done in both the military and civil spheres to enable the Union to succeed. His arrogant need to be at the forefront of every decision can be gleaned from this letter. No other commander would deem it necessary or prudent to dictate to the President what roles the military and civil authorities should have in the conduct of the war. McClellan's intense need to be the focus of attention drove him to write this letter to the President with a clear conscience, believing that he was doing what was correct for the country.

Next, McClellan lashed out at the Secretary of War, Edwin Stanton for not providing him enough troops in his march to Richmond. Upon becoming Secretary of War, Stanton had become one of McClellan's staunchest opponents. Stanton felt that the general moved too slowly and that McClellan was prone to blame all others but himself. McClellan's actions during the Peninsula campaign affirmed that assessment. In a July13, 1862 letter to Mary Ellen McClellan, McClellan discussed what a traitor Stanton had become to him. He believed that if Edwin Stanton had been an Apostle; Judas Iscariot would have continued to be a respected member of the Apostles and he would have been horrified by the treachery of Edwin Stanton. ${ }^{165}$ General McClellan also

${ }^{164}$ McClellan to Abraham Lincoln, Harrison's Landing, VA, July 7, 1862, in The Civil War Papers of George B. McClellan: Selected Correspondence 1860-1865, ed. Stephen W. Sears (New York: Da Capo Press, 1989), 344-45.

${ }^{165}$ McClellan to Mary Ellen McClellan, Berkeley, VA, July 13, 1862, in The Civil War Papers of George B. McClellan: Selected Correspondence: 1860-1865, ed. Stephen W. Sears (New York: Da Capo Press), 354. 
explained that he did not want to be the Secretary of War; but he would take the position if that is what the country wanted and needed. ${ }^{166}$ His arrogance once again played a prominent part in his thoughts on the Secretary of War. Since Stanton would not go along with the plans that McClellan had set forth, the general saw no need for him. Instead, with his refusal of wanting to become Secretary of War, it becomes apparent that McClellan had thought about trying to achieve the position. Stanton and McClellan's relationship would not get any better with the naming of a new General-in-Chief, this time General Henry Halleck. In another letter to his wife on July 20, 1862 he lamented that he would have to serve under a man that he knew was inferior to himself, but McClellan took solace in the fact that he believed he would be relieved of all his duties as soon as the politicians found a justification for his removal. ${ }^{167}$ Although he thought otherwise, McClellan's time in the Army would not end with the Peninsula Campaign; instead the, Lincoln administration called on McClellan one last time after the Second Battle of Bull Run. On September 2, 1862 McClellan was called on take charge of the defenses of Washington against an anticipated attack by Confederate troops.

McClellan arrived in Washington and set about doing what he did best, training and equipping the troops that were in his charge. Although he was placed only in command of the defenses of Washington, after hearing that Confederate troops had moved into Maryland, General Halleck allowed McClellan to move the forces that protected Washington to the field in anticipation of fighting the Confederates. In a letter to his wife dated September 6,1862, McClellan explained that he has once more been

${ }^{166}$ Ibid., 355.

${ }^{167}$ McClellan to Mary Ellen McClellan, Berkeley, VA, July 20, 1862, in The Civil War Papers of George B. McClellan: Selected Correspondence: 1860-1865, ed. Stephen W. Sears (New York: Da Capo Press), 367-68. 
called upon to save the country and that the help of God he would deliver the country from this peril. ${ }^{168}$ In undated notes for an article on the Maryland Campaign McClellan noted the problems that were involved in getting the army prepared for an engagement with the Confederate forces. In the notes McClellan explained that he discussed with both Secretary of State William Seward and General Halleck the need to relinquish control of the Federal garrison at Harper's Ferry and unite that garrison with the main body of the Army.$^{169}$ McClellan also felt that since the Union force did not have an overall commander this would lead to a breakdown in the Army. McClellan decided to assume command himself even though he understood that if the Union forces lost in Maryland he would quite possibly be tried for assuming command without authorization. ${ }^{170}$ McClellan took these troops into Maryland to face the force that was threatening the entire Union. Thus started the campaign that would end with the Battle of Antietam on September 17,1862, and what McClellan thought was the redemption that he had been seeking.

During this campaign, on September 13, 1862, as luck would have it, Union soldiers stumbled upon orders that had been written by General Robert E. Lee, the Commander of the Army of Northern Virginia, outlining the Confederate battlefield plans for the Maryland Campaign. McClellan used these plans to disrupt Lee and instigate a

${ }^{168} 168$ McClellan to Mary Ellen McClellan, Berkeley, VA, September 5, 1862, in The Civil War Papers of George B. McClellan: Selected Correspondence: 1860-1865, ed. Stephen W. Sears (New York: De Capo Press), 367-68

${ }^{169}$ Notes by George B. McClellan, undated, reel 69, George Brinton McClellan Papers, Library of Congress, Washington DC. The Library of Congress has an extensive amount of McClellan Papers within their collections. Unfortunately, the papers have been placed on microfilm and the film is old and deteriorated. Also, many of the documents were written on both the front and back which leads to a bleed over effect on the microfilm. These deficiencies render much of the collection illegible.

${ }^{170}$ Notes, undated, McClellan Papers. 
fight with his Confederate foes at a time and place of his choosing. That battlefield was at Antietam, in the vicinity of Sharpsburg, Maryland. The Union won the battle, but was unable to press the advantage once the Confederate forces retreated during the night of September 17, 1862. Instead, McClellan believed that he had done all he had set out to do -- save the Union from Confederate forces. McClellan did believe that he could have crushed the Confederates at Antietam, but like many other episodes, it was not his fault that he was unable to do so. Instead, McClellan laid the blame on one of his corps commanders, Major General Ambrose Burnside. In a September 29, 1862 letter to his wife, McClellan commented that Burnside did not deserve to command any force larger than a regiment, but expressed his desire to stay friends with Burnside even though he was going to give him a thorough thrashing for not following orders. ${ }^{171}$ He also lamented that he would probably make an enemy for life, but the alternative was to praise him which McClellan was not going to do. ${ }^{172}$ Sadly, McClellan did not understand the circumstances surrounding the actions of General Burnside. Burnside's corps was unable to ford the river that separated them from the enemy and when the corps attempted to use the bridge that crossed the river found that the Confederate troops had amassed their fire to that spot. Also, Burnside's corps did not have sufficient ammunition to combat the intense gunfire leveled against them. After some time, Burnside broke through, but it was all for naught as he was pushed back by Confederate reinforcements. In actuality, it was McClellan's decision to send in his attacks piecemeal against the Confederate front that led to the stalemate at Antietam, not the inability of Burnside to take the right flank

${ }^{171}$ McClellan to Mary Ellen McClellan, Sharpsburg, MD, September 29, 1862," The Civil War Papers, of General George B. McClellan: Selected Correspondence 18601865, ed. Stephen W. Sears (New York: Da Capo Press, 1989), 485-486.

${ }^{172}$ McClellan to McClellan, 485-486. 
of the enemy.

McClellan never made an effort to crush the retreating rebel army even though the Confederates had to cross the Potomac River in order to make it safely back to their lines in Virginia. President Lincoln saw this moment as an opportunity to crush the Confederate Army but it slipped away as the last remnants made it safely across the river. McClellan was overjoyed with the success that he enjoyed on the battlefield and on September 20,1862 , even wrote a letter to his wife proclaiming that all of his political enemies were finished because he had won such a dramatic victory. ${ }^{173} \mathrm{He}$ also commented that Stanton should resign from his office and that General Halleck should resign from his command since McClellan was more qualified as General-in-Chief. ${ }^{174}$ McClellan's personal ambition showed itself one more time after the battle of Antietam. He moved the enemy out of Union territory, and he believed that it was enough to be given back the position of General-in-Chief. Unfortunately for McClellan, the President felt that McClellan should have done a lot more than move the Confederate troops out of Maryland. Abraham Lincoln believed that McClellan missed a golden opportunity to destroy the Confederate Army at Antietam and then compounded the problem by not following the retreating troops.

McClellan followed the Confederate Army at a safe distance, but he never fought a large engagement again. On November 10, 1862 President Lincoln relieved General George McClellan as Commander of the Army of the Potomac, a position that he had enjoyed since its inception. The final straw was the lack of pace in McClellan's

${ }^{173}$ McClellan to Mary Ellen McClellan, Sharpsburg, MD, September 20, 1862, in The Civil War Papers of George B. McClellan: Selected Correspondence: 1860-1865, ed. Stephen W. Sears (New York: Da Capo Press), 473.

${ }^{174}$ McClellan to McClellan, 473. 
attempts to gain Richmond for the Union. Although McClellan left the scene still on active duty, the Army and nation did not call upon him for active military duty for the rest of the war. There are many reasons why in the end McClellan was relieved of his command. One of the biggest was his arrogance. From the outset of hostilities, McClellan's arrogant attitude towards all who did not have the same point of view placed him in various precarious positions. Although he attained the position of Major General, first with the Ohio volunteer corps and progressed through the ranks until he supplanted General Winfield Scott as General-in-Chief in what can only be described as a hostile take-over, that same personality trait, his arrogance, led to his downfall. Although McClellan held aspirations to perhaps become dictator, certainly Secretary of War, and savior of the Union, it was his hubristic tone with those that were his subordinates and superiors that led to his downfall. In the end, it was McClellan's arrogance that turned those in power against him and when it came time to relieve him of his duties, McClellan had no political allies left to help him out of the crisis of his own making. 


\section{CHAPTER VI}

\section{CONCLUSION}

George McClellan's rise and fall during the initial stages of the Civil War has been examined by various scholars throughout the years. However, many of those scholars focused on the aspects of the war and McClellan's personality that were out of McClellan's control such as the weather, his political heritage as a moderate Democrat in the face of radical Republicans, and his relationship with the Lincoln administration. In this essay three factors account for McClellan's rise and fall. Although McClellan is thought of as being a difficult person to understand, examining these factors allows the reader to develop a sharper focus on the thought processes and timing of McClellan and the reasoning behind the decisions made by him and others become clearer. This thesis focused on McClellan's historical moment, McClellan's dual reality, and McClellan's arrogant, often hubristic, decision-making process.

The examination of McClellan was divided into four sections in order for the reader to fully comprehend the nuances of McClellan's personality and world. The first chapter focused on the historiography and the differing opinions scholars have had on McClellan through the years. It was eye-opening to see the vast array of hagiographies written by scholars in the past and even more so by those scholars in the modern age. Although there has been a shift in the historiography, the focus continues to be the fight between "good" and "bad" general. The chapter on McClellan's historical moment 
confronts the fundamental issue of timing. Although he made various mistakes, the Lincoln administration allowed him to continue in his command. This chapter confronted the reasons behind this choice. Even though some of the reasons were straight forward, others only became clear after analyzing the military, political and civil landscape of the Civil War. The third chapter dealt with the duel reality of McClellan's nature. The chapter examined how McClellan created a different reality than the one of those around him. He used this alternate reality to create foes that were not there which led to his hyper-inflation of enemy troops. The final chapter analyzed the McClellan's arrogant attitude towards both his superiors and his subordinates. His arrogance led him to believe that he was the one with all the answers and eventually led to him becoming distrustful of those that did not have the same views. The arrogance displayed by McClellan was the overarching reason for his fall from the ranks of the military during the war.

Although scholars have begun to focus on McClellan; room exists for further study. Unlike other generals of the period, who have copious amounts of literature devoted to them, scholars have just scratched the surface with McClellan. Whether it is because of his hubris towards his superiors and subordinates or his perceived failure as a battlefield commander, many scholars have chosen to study more likeable figures. But if the Civil War is to be understood, the villains must be studied as much as the heroes. For every Grant and Sherman there is a McClellan waiting to be further scrutinized. In the recent past, scholars have begun to delve into the life of General McClellan, it has been centered on his Civil War military experience. Multiple areas of his life exist that still need to be explored, such as his early life and his personal and professional life after his 
term of service in the war. Not only does General George B. McClellan exist as a topic of further research and interpretation, so too does General George B. McClellan, the enigma, exist to challenge future scholars. 


\section{REFERENCES}

\section{Primary Sources:}

Unpublished Primary Sources:

George B. McClellan Papers, Library of Congress, Washington DC.

Published Primary Sources:

Association of Graduates, USMA. Register of Graduates and Former Cadets of the United States Military Academy: Cullum Memorial Edition. Crawfordsville, IN:

R. R. Donnelley and Sons Company, 1980.

Grant, Ulysses S. Personal Memoirs of U.S. Grant. Linoln: University of Nebraska Press, 1996.

Lincoln, Abraham. Lincoln to George B. McClellan, Washington, July 13, 1862. In The Collected Works of Abraham Lincoln. Volume 5, edited by Roy P. Basler. Piscataway, NJ: Rutgers University Press, 1953.

McClellan, George B. The Civil War Papers of George B. McClellan: Selected Correspondence 1860-1865, edited by Stephen W. Sears. New York: Da Capo Press, 1989.

McClellan, George B. McClellan's Own Story. Edited by William C. Prime. New York: Charles L. W. Webster, 1887.

McClellan, George B. McClellan to Henry Halleck, Report, August 3, 1863. In The War of the Rebellion: A Compilation of the Official Records of the Union and Confederate Armies. Series I, Volume XI, PartI: Reports, edited by Bvt. Lt. Col. Robert N. Scott. Washington: Government Printing Office, 1884. Reprint, Gettysburg, PA: National Historical Society, 1972.

Sherman, William T. Memoirs of General William T. Sherman. New York: Da Capo Press, 1984.

\section{Secondary Sources:}


Articles:

Curtis, George Ticknor. "McClellan's Last Service to the Republic, Part I." The North A American Review, 130, (April 1880): 309-337.

. "McClellan's Last Service to the Republic, Part II." The North American Review, 130, (May 1880): 462-478.

. "McClellan's Last Service to the Republic, Part III." The North American Review, 130, (May 1880): 565-584. Fishel, Edwin C. "The Mythology of Civil

War Intelligence." Civil War History, 10, $\quad$ (December 1964): 344-367.

Harsh, Joseph L. "On the McClellan-Go-Round." Civil War History, 19, (June 1973): 101-118.

Sears, Stephen W. "The Curious Case of General McClellan's Memoirs." Civil War History, 34, (June 1988): 101-114.

Books:

Addey, Markenfield. George Brinton McClellan: from Cadet to Major-General: A

Biography. New York: James G. Gregory, 1864.

Badeau, Adam. Military History of Ulysses S. Grant, from April 1861, to April 1865.

New York: D. Appleton, 1881.

Bass, Cynthia. Sherman's March. New York: Villard Books, 1994.

Bonekemper, Edward H. McClellan and Failure: A Study of Civil War Fear, Incompetence, and Worse. Jefferson, NC: McFarland and Company, 2007.

Campbell, James Havelock. McClellan: a Vindication of the Military Career of General George B. McClellan: A Lawyer's Brief. New York: Neale Publishing Company, 1916.

Catton, Bruce. The Army of the Potomac: Mr. Lincoln's Army. Garden City, NY: D Doubleday, 1962. .U. S. Grant and the American Military Tradition. Boston: Little, Brown, 1954.

Eicher, David J. Longest Night: A Military History of the Civil War. New York: Simon \& Schuster, 2001.

Glatthaar, Joseph. Partners in Command: The Relationship Between Leaders in the Civil War. New York: The Free Press, 1994. 
Hassler, Warren W. General George B. McClellan: Shield of the Union. Baton Rouge: Louisiana State University Press, 1957.

McFeely, William S. Grant: A Biography. New York: Newton, 1981.

Michie, Peter S. General McClellan. New York: D. Appleton and Company, 1901.

Rafuse, Ethan S. McClellan's War: The Failure of Moderation in the Struggle for the Union. Bloomington: University of Indiana Press, 2005.

Rowland, Thomas J. George B. McClellan and Civil War History: In the Shadow of Grant and Sherman. Kent, OH: Kent State University Press, 1998.

Royster, Charles. William Tecumseh Sherman, Stonewall Jackson, and the Americans. New York: Knopf, 1991.

Sears, Stephen W. George B. McClellan: The Young Napoleon. New York: Ticknor and Fields, 1988.

. To The Gates of Richmond: The Peninsula Campaign. New York: Ticknor and Fields, 1992.

Simpson, Brooks D. Ulysses S. Grant: Triumph over Adversity, 1822-1865. New York: Houghton-Mifflin, 2000.

Waugh, John C. Lincoln and McClellan: The Troubled Partnership Between a President and His General. New York: Palgrave Macmillan, 2010.

Williams, T. Harry. Lincoln and His Generals. New York: Knopf, 1952. 


\section{CURRICULUM VITAE}

NAME: $\quad$ Carl Wesley Pagles

ADDRESS: 675 North Barbee Way

Louisville, KY 40217

DOB: $\quad$ Greenville, Pennsylvania - March 14, 1977

EDUCATION

\& TRAINING:

A.A., Spanish

Defense Language Institute

2009

B.S., History

Cumberland College

1999

AWARDS:

PROFESSIONAL SOCIETIES: Golden Key International Honor Society 2011

Phi Alpha Theta, History Honors Society 2011

PUBLICATIONS: $\quad$ C. Wesley Pagles, a review of The Notorious "Bull Nelson": Murdered Civil War General, by Donald A. Clark, Ohio Valley History 11, no. 2 [Summer 2011]: 82-83.

NATIONAL MEETING PRESENTATIONS:

REFEREED JOURNALS:

BOOKS AND SYMPOSIA:

INVITED PRESENTATIONS: 